\title{
An Evaluation of the Effectiveness of Sorbents in the Remediation of Soil Contaminated with Zinc
}

\author{
Rafal Strachel • Jadwiga Wyszkowska • \\ Malgorzata Baćmaga
}

Received: 9 February 2018 / Accepted: 20 June 2018 /Published online: 1 July 2018

(C) The Author(s) 2018

\begin{abstract}
Zinc exerts negative effects on soil and contributing to the degradation of soil ecosystems. New solutions for restoring healthy soil activity are therefore needed. The aim of this study was to evaluate the effectiveness of sorbents in the biological remediation of soil contaminated with zinc. A pot experiment was conducted on loamy sand. The tested plant was maize (Zea mays). Soil was contaminated with zinc chloride doses of $0,100,300$, and $900 \mathrm{mg} \mathrm{Zn}^{2+} \mathrm{kg}^{-1} \mathrm{DM}$ soil (dry matter of soil). Alginate, biochar, sepiolite, calcined halloysite, and a molecular sieve were added to soil in amounts corresponding to $2.5 \%$ of soil weight to minimize zinc's potentially toxic effects on the biological properties of soil. The application of zinc stimulated the proliferation of all analyzed microbial groups. Zinc exerted negative effects on the ecophysiological diversity (EP) of fungi and the activity of dehydrogenases, catalase, and acid phosphatase. The applied sorbents modified the microbiological and biochemical properties of soil. In zinc-contaminated soil, alginate, biochar, and molecular sieve increased the counts of organotrophic, oligotrophic, and actinobacteria. Sorbents were not highly effective in promoting fungal growth and exerted varied effects on the activity of soil enzymes. The molecular sieve stimulated the activity of all soil enzymes, excluding $\beta$-glucosidase. Alginate minimized the negative influence of zinc on dehydrogenases and acid phosphatase, and biochar — on catalase, sepiolite, and calcined halloysite
\end{abstract}

R. Strachel $\cdot$ J. Wyszkowska $(\bowtie) \cdot$ M. Baćmaga

Department of Microbiology, University of Warmia and Mazury in Olsztyn, Plac Łódzki 3, 10-727 Olsztyn, Poland

e-mail: jadwiga.wyszkowska@uwm.edu.pl -on acid phosphatase. By modifying the biological properties of soil, the tested sorbents contributed to an increase in maize yields and a decrease in zinc uptake by maize plants.

Keywords Pollution · Sorbents · Remediation of soil · Microorganisms $\cdot$ Enzymes $\cdot$ Biodiversity

\section{Introduction}

Over the decades, human activities have contributed to a disruption in soil biological activity. Environmental pollution caused by chemical compounds, including heavy metals, exerts negative effects on ecosystems and crop production (Mahar et al. 2016). Heavy metals are persistent pollutants, and they pose a problem in both urban and rural areas when their accumulation in soil exceeds safe levels. The quantity of trace elements in the environment does not change over time, and these elements can only be transformed into biologically available or unavailable forms (Khalid et al. 2017). The availability of heavy metals in soil is closely associated with the physicochemical properties of soil. Biologically available heavy metals are present in the soil solution or they occur as exchangeable fractions bound to organic or inorganic soil components. Metals that are not available to plants are strongly bound to soil particles; they are present in the crystal lattice of soil minerals or form insoluble deposits. Changes in the physicochemical properties of soil, i.e., $\mathrm{pH}$, cation-exchange capacity, content of organic matter, clay minerals, $\mathrm{Fe}, \mathrm{Al}$, and $\mathrm{Mn}$ oxides, and redox potential, can lead to the 
transformation of biologically unavailable compounds into plant-available forms (Aydinalp and Marinova 2003).

Zinc is an essential element for living organisms (Krężel and Maret 2016). However, elevated zinc concentrations can disrupt the biological balance (Strachel et al. 2017). Excessive accumulation of zinc in soil can deteriorate the physicochemical and biological properties of soil, which leads to soil degradation and renders soil unfit for agricultural production (Wyszkowska et al. 2016). In zinccontaminated habitats, effective measures are required to restore the biological functions of soil. Soil remediation is one of the most popular solutions that address this problem. Pollutants can be extracted from soil, but the relevant measures are costly and time-consuming. Soil pollutants can also be stabilized with the use of various substances that decrease the mobility of heavy metals. Solutions applied in situ are less expensive and can be applied over larger areas of contaminated land (Pérez de Mora et al. 2005).

The use of organic and inorganic adsorbents to stabilize the chemical composition of soil contaminated with heavy metals is an economical and environmentally friendly remediation method. Adsorbents immobilize heavy metals and minimize their adverse effects on living organisms, in particular soil-dwelling microorganisms and plants (Malandrino et al. 2011).

Various organic substances are increasingly often used to reduce the availability of metals in soil and minimize the adverse environmental impact of zinc. These substances reduce the mobility of contaminants by binding chemical elements or modifying local environmental conditions to decrease their solubility (Bradl 2004). The influence of sorbents with remediation potential on zinc-contaminated soil was investigated in this study. The effectiveness of alginate, biochar, sepiolite, calcined halloysite, and a molecular sieve was evaluated in soil cotaminated with zinc. Due to the complexity of the soil environment, the remediation potential of the tested sorbents was analyzed based on changes in the counts and diversity of soil-dwelling microorganisms, changes in the biochemical activity and physicochemical properties of soil, and the development of maize plants.

\section{Materials and Methods}

\subsection{Soil}

The experiment was performed on brown calcic soil developed from loamy sand. Soil was sampled at the area north-eastern Poland $\left(53.7161^{\circ} \mathrm{N}, 20.4167^{\circ} \mathrm{E}\right)$. The properties of the experimental soil have been described in detail in a previous study Strachel et al. (2017).

\subsection{Sorbents}

Five sorbents were evaluated in a pot experiment: alginate, biochar, sepiolite, calcined halloysite, and a molecular sieve.

Alginate was manufactured by VázsonySzövetkezeti Kft. (Hungary). This mineral compound is a rich source of nutrients. According to label data, the product contains $\left(\mathrm{g} \mathrm{kg}^{-1}\right)$ : humic substances - 200-300, $\mathrm{Ca}-100-300, \mathrm{~N}-3-5, \mathrm{P}-5-6, \mathrm{~K}-6-9$, and $\mathrm{Mg}-8-$ 10. Alginate also contains trace amounts of $\mathrm{Mn}, \mathrm{Cu}, \mathrm{Zn}$, $\mathrm{Fe}, \mathrm{B}$, and $\mathrm{Mo}$. The $\mathrm{pH}$ values of alginate are $\mathrm{pH}_{\mathrm{KCl}}$ 6.7 and $\mathrm{pH}_{\mathrm{H} 2 \mathrm{O}}-7.2$.

Biochar was manufactured by Fluid company (Poland). The product is made from organic material via pyrolysis. Biochar has the following chemical composition: stable $\mathrm{C}-$ more than $77 \%$, volatile matter $-17 \%$, ash-less than $6 \%$, chlorides, sulfur, and mercury-less than $0.01 \%$. The $\mathrm{pH}$ values of biochar are $\mathrm{pH}_{\mathrm{KCl}}-8.0$ and $\mathrm{pH}_{\mathrm{H} 2 \mathrm{O}}-9.0$.

Sepiolite $60 / 100$ contains sepiolite $\left(\mathrm{Mg}_{4}\left[\mathrm{Si}_{6} \mathrm{O}_{15}(\mathrm{OH})_{2}\right] 6 \mathrm{H}_{2} \mathrm{O}\right)$, and it was manufactured by the Sepiolsa Minersa Group (Spain). Sepiolite is hydrated magnesium silicate with adsorptive properties. According to label data, the product contains $70 \%$ sepiolite, including $85 \%$ of particles with the size of 75 to $710 \mu \mathrm{m}$. The $\mathrm{pH}$ values of sepiolite are $\mathrm{pH}_{\mathrm{KCl}}-7.1$ and $\mathrm{pH}_{\mathrm{H} 2 \mathrm{O}}-7.1$.

Halloysite $\left(\mathrm{Al}_{2} \mathrm{Si}_{2} \mathrm{O}_{5}(\mathrm{OH})_{4}\right)$ is a clay mineral which is used in the production of Halosorb mineral sorbents (Intermark, Poland). The mineral used in this experiment was mined in Dunino (Poland), and it has the following chemical composition: $\mathrm{SiO}_{2}-40 \pm 1 \%$, $\mathrm{Fe}_{2} \mathrm{O}_{3} / \mathrm{FeO}-8 \pm 1 \%, \mathrm{TiO}_{2}-2 \pm 1 \%, \mathrm{Al}_{2} \mathrm{O}_{3}-33 \pm 1 \%$, $\mathrm{MgO}-0.5 \pm 0.1 \%, \mathrm{CaO}-1.3 \pm 0.2 \%, \mathrm{Na}_{2} \mathrm{O}-0.1 \%$, and $\mathrm{K}_{2} \mathrm{O}-0.1 \%$. Halloysite is characterized by a large specific surface area, high porosity, and high cationexchange capacity. Halloysite was calcined before the experiment. The $\mathrm{pH}$ values of halloysite are $\mathrm{pH}_{\mathrm{KCl}}-5.9$ and $\mathrm{pH}_{\mathrm{H} 2 \mathrm{O}}-6.5$.

The Sylosiv A3 molecular sieve was manufactured by Grace Davison Company (USA). This synthetic nanoporous material consists of crystalline aluminosilicate with 0.3-nm micropores. Molecular sieve powder is a zeolite with a three-dimensional pore system and extensive adsorption capacity. It is available in the form 
of white odorless powder. The $\mathrm{pH}$ values of molecular sieve are $\mathrm{pH}_{\mathrm{KCl}}=8.5$ and $\mathrm{pH}_{\mathrm{H} 2 \mathrm{O}}-10.2$.

\subsection{Experimental Design}

A pot experiment was conducted in the greenhouse in five replications. Soil material in the amount of $3 \mathrm{~kg}$ of air-dried soil was placed in $3.5-\mathrm{dm}^{3}$ polyethylene pots with various doses of zinc, remediation substances, and mineral fertilizers. Zinc was applied as $\mathrm{ZnCl}_{2}$ in doses of 0, 100, 300, and $900 \mathrm{mg} \mathrm{Zn}^{2+} \mathrm{kg}^{-1} \mathrm{DM}$ soil. The tested sorbents-alginate, biochar, sepiolite, calcined halloysite, and a molecular sieve- - were applied to soil in amounts corresponding to $2.5 \%$ of soil weight. Four zinc doses and six types of sorbents were analyzed in five replications - a total of 120 pots. The tested plant was maize which was grown for 60 days. Water content at the level of $50 \%$ of the maximum capacity of the soil was maintained throughout the entire experimental period. The following mineral fertilization was applied (pure element per $\mathrm{mg} \mathrm{kg}^{-1}$ soil): $\mathrm{N}-100, \mathrm{P}-50, \mathrm{~K}-$ $100, \mathrm{Mg}-25, \mathrm{Cu}-5, \mathrm{Mn}-5, \mathrm{Mo}-2.5$, and $\mathrm{B}-0.33$. Mineral fertilizers were applied in the following forms: nitrogen-as $\mathrm{CO}\left(\mathrm{NH}_{2}\right)_{2}$, phosphorus - as $\mathrm{KH}_{2} \mathrm{PO}_{4}$, potassium-as $\mathrm{KH}_{2} \mathrm{PO}_{4}+\mathrm{KCl}$, magnesium-as $\mathrm{MgSO}_{4} \cdot 7 \mathrm{H}_{2} \mathrm{O}$, copper-as $\mathrm{CuSO}_{4} \cdot 5 \mathrm{H}_{2} \mathrm{O}$, manganese-as $\mathrm{MnCl}_{2} \cdot 4 \mathrm{H}_{2} \mathrm{O}$, molybdenum-as $\mathrm{Na}_{2} \mathrm{MoO}_{4} \cdot 2 \mathrm{H}_{2} \mathrm{O}$, and boron-as $\mathrm{H}_{3} \mathrm{BO}_{3}$. Maize was sown at 12 seeds per pot. Seedlings were thinned to leave nine plants per pot. Maize plants were harvested in stage BBCH 53 (inflorescence emergence - tip of inflorescence visible) and dried at a temperature of $60{ }^{\circ} \mathrm{C}$ until the achievement of constant weight. Microbiological and biochemical analyses of soil were performed in triplicate for each soil sample on days 30 and 60 of the experiment. The physicochemical properties of soil were determined on day 60 , in triplicate for each sample.

\subsection{Analyses}

Microbial counts and enzyme activity in soil samples were determined in three replicates on experimental days 30 and 60 . The physicochemical properties of soil and zinc concentrations in soil and plant material were determined on day 60 .

Microbiological analyses were carried out by the plating method to determine the counts of microorganisms. The counts of organotrophic bacteria, actinobacteria, and fungi were estimated over a period of 10 days in daily intervals to determine the ecophysiological diversity (EP) index of microorganisms according to Eq. (1) (De Leij et al. 1993). The activity of dehydrogenases, catalase, urease, acid phosphatase, alkaline phosphatase, and $\beta$-glucosidase was determined in soil. Microbiological and enzymatic analyses have been described in detail in a study Borowik et al. (2017).

The activity of soil enzymes (dehydrogenases, catalase, acid phosphatase, alkaline phosphatase, urease, and $\beta$-glucosidase) was used to calculate the soil biochemical quality index (BA) based on Eq. (2) (Wyszkowska et al. 2013) and to determine soil resistance (RS) to zinc pollution according to Eq. (3) (Orwin and Wardle 2004). Microbial counts and enzyme activity were also used to calculate the zinc impact factor $\mathrm{IF}_{\mathrm{Zn}}$ (Eq. 4) and the sorbent impact factor $\mathrm{IF}_{\mathrm{S}}$ (Eq. 5) (Kaczyńska et al. 2015).

$\mathrm{EP}=-\sum(\mathrm{pi} \cdot \log \mathrm{pi})$

where

EP ecophysiological diversity index of microorganisms,

pi share of individuals of the $i^{\text {th }}$ species in the community relative to the total number of individuals in the community

$\mathrm{BA}=\mathrm{Deh}+\mathrm{Cat}+\mathrm{Pac}+\mathrm{Pal}+\mathrm{Ure}+\mathrm{Glu}$

where

BA biochemical quality index,

Deh activity of dehydrogenases $\left(\mu \mathrm{mol} \mathrm{TFF} \mathrm{kg}{ }^{-1} \mathrm{DM}\right.$ of soil $\mathrm{h}^{-1}$ ),

Cat activity of catalase $\left(\operatorname{mol~O} \mathrm{kg}^{-1} \mathrm{DM}\right.$ of soil h $\left.\mathrm{h}^{-1}\right)$,

$\mathrm{Pac}$ activity of acid phosphatase (mmol PNP kg ${ }^{-1}$ DM of soil h${ }^{-1}$ ),

Pal activity of alkaline phosphatase (mmol PNP kg-1 DM of soil h${ }^{-1}$ ),

Ure activity of urease (mmol N-NH4 kg ${ }^{-1}$ DM of soil $\mathrm{h}^{-1}$ ),

Glu activity $\beta$-glucosidase (mmol PNP kg ${ }^{-1} \mathrm{DM}$ of soil $\mathrm{h}^{-1}$ ).

$\operatorname{RS}\left(t_{0}\right)=1-\frac{2\left|D_{0}\right|}{C_{0}+\left|D_{0}\right|}$

where 
RS soil resistance index;

$C_{0} \quad$ soil resistance under natural conditions over time $t_{0}$;

$P_{0} \quad$ resistance of soil subjected to pressure over time $t_{0} ; D_{0}=C_{0}-P_{0}$.

The soil resistance index (RS) varies from -1 to 1 . If the value of RS is -1 and 0 , zinc exerts a very strong effect on soil. If the value of RS approximates 1, soil is more resistant to zinc.

$\mathrm{IFZn}=\frac{A_{\mathrm{Zn}}}{A_{0}}$

where

$\mathrm{IF}_{\mathrm{Zn}}$ zinc impact factor,

$A_{Z n} \quad$ enzyme activity or microbial counts in soil contaminated with zinc,

A enzyme activity or microbial counts in uncontaminated soil.

$\mathrm{IFZn}=\frac{A_{\mathrm{S}}}{A}$

where

$\mathrm{IF}_{\mathrm{s}}$ sorbent impact factor,

$A_{S}$ enzyme activity or microbial counts in soil with the addition of sorbents,

A enzyme activity or microbial counts in soil without the addition of sorbents.

The physicochemical parameters of soil and the content of plant-available zinc and total zinc in soil (flame atomic absorption spectrometry method - FAAS) were determined according to Harris (2006). The detection limit was $96 \mu \mathrm{g} \mathrm{dm}^{-3}$ for total zinc and $13 \mu \mathrm{g} \mathrm{dm}{ }^{-3}$ for bioavailable zinc. Uncertainty was estimated at a confidence level of $p=0.95$ and coverage factor $k=2$. To determine total zinc content, soil samples were digested in a mixture of concentrated $\mathrm{HCl}$ and $\mathrm{HNO}_{3}$. Bioavailable zinc content was determined after extraction with $1 \mathrm{M} \mathrm{HCl}$. The distribution of zinc in plants was determined based on zinc concentrations in the aerial parts and roots of maize plants (Zacchini et al. 2009).

\subsection{Statistical Analysis}

The results were processed statistically in Statistica 12.0 software (StatSoft Inc. 2014) at a significance level of $p=0.05$. The percentage contribution of the experimental factors to the observed variation $\left(\eta^{2}\right)$ was determined. Microbial counts and enzyme activity were subjected to principal component analysis (PCA). Homogeneous groups were identified by Tukey's HSD test.

\section{Results}

\subsection{Microbial Properties of Soil}

The results of the study (Table 1) indicate that the type of sorbent exerted the greatest influence on microbial counts, ranging from $37.17 \%$ for copiotrophic bacteria to $51.80 \%$ for organotrophic bacteria. Zinc dose induced somewhat smaller changes in microbial counts, and its influence ranged from $15.29 \%$ for organotrophic bacteria to $33.70 \%$ for copiotrophic bacteria. Microbial counts were least affected by the date of analysis $(0.33$ to $5.93 \%$ ).

In the principal component analysis (Fig. 1a), soil microorganisms were divided into two groups based on their responses to the experimental factors. The first group was composed of organotrophic bacteria, copiotrophic bacteria, oligotrophic bacteria, and actinobacteria. The second group consisted of fungi which responded differently to the analyzed factors. The counts of bacteria and actinobacteria were most influenced by biochar, molecular sieve, and alginate, and they were least influenced by sepiolite (Fig. 1b). The above results were inferred from the projection of cases describing treatments with the tested sorbents

Table 1 Percentage contribution of the experimental factors to the observed variation $\left(\eta^{2}\right)$ in microbial counts in zinc-contaminated soil

\begin{tabular}{lrrrrr}
\hline Factors & Org & \multicolumn{1}{c}{ Cop } & Olig & Act & Fun \\
\hline Dose of Zn (a) & 15.29 & 33.70 & 25.67 & 19.43 & 31.50 \\
Sorbents (b) & 51.80 & 37.17 & 43.70 & 45.55 & 54.38 \\
Time (c) & 0.33 & 1.97 & 0.33 & 5.93 & 4.25 \\
$\mathrm{a} \cdot \mathrm{b}$ & 10.49 & 14.12 & 7.68 & 7.21 & 4.42 \\
$\mathrm{a} \cdot \mathrm{c}$ & 0.52 & 2.37 & 1.28 & 1.35 & 1.94 \\
$\mathrm{~b} \cdot \mathrm{c}$ & 6.47 & 1.05 & 11.66 & 12.52 & 0.98 \\
$\mathrm{a} \cdot \mathrm{b} \cdot \mathrm{c}$ & 11.63 & 6.75 & 8.38 & 5.23 & 1.50 \\
Error & 3.47 & 2.87 & 1.30 & 2.78 & 1.03 \\
\hline
\end{tabular}

Zn zinc, Org organotrophic bacteria, Cop copiotrophic bacteria, Olig oligotrophic bacteria, Act actinobacteria, Fun fungi 


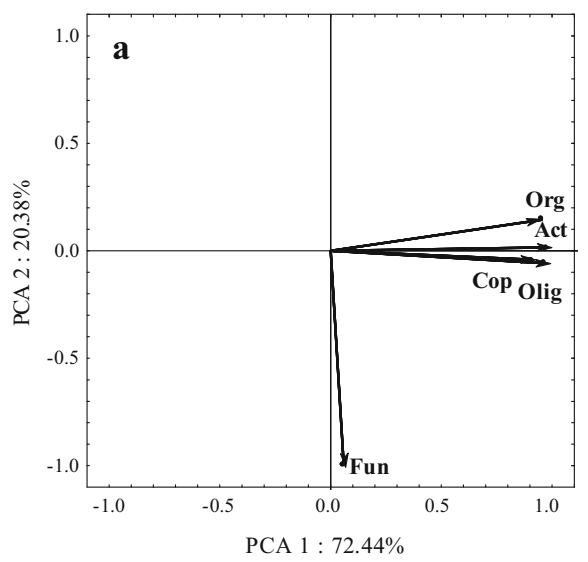

Fig. 1 Microbial counts in zinc-contaminated soil in principal component analysis (PCA). a Projection of vectors onto a plane describing microbial counts. b Projection of cases onto the plane. Org organotrophic bacteria, Cop copiotrophic bacteria, Olig

relative to the vectors describing microbial counts. Fungal counts were highest in treatments with zinc doses of 300 and $900 \mathrm{mg} \mathrm{Zn}^{2+} \mathrm{kg}^{-1} \mathrm{DM}$ soil.

The calculated values of $\mathrm{IF}_{\mathrm{Zn}}$ indicate that zinc exerted varied effects on microbial counts (Fig. 2). In treatments without sorbents, increasing doses of zinc (100 to $900 \mathrm{mg} \mathrm{Zn}^{2+} \mathrm{kg}^{-1} \mathrm{DM}$ soil) increased the proliferation of copiotrophic bacteria, oligotrophic bacteria, actinobacteria, and fungi. The growth of organotrophic bacteria was inhibited only by the highest zinc dose (900 $\mathrm{mg} \mathrm{Zn}^{2+} \mathrm{kg}^{-1} \mathrm{DM}$ soil). Based on the calculated values of $\mathrm{IF}_{\mathrm{Zn}}$, the evaluated soil-dwelling microorganisms were arranged in the following order (from most resistant to most sensitive): copiotrophic

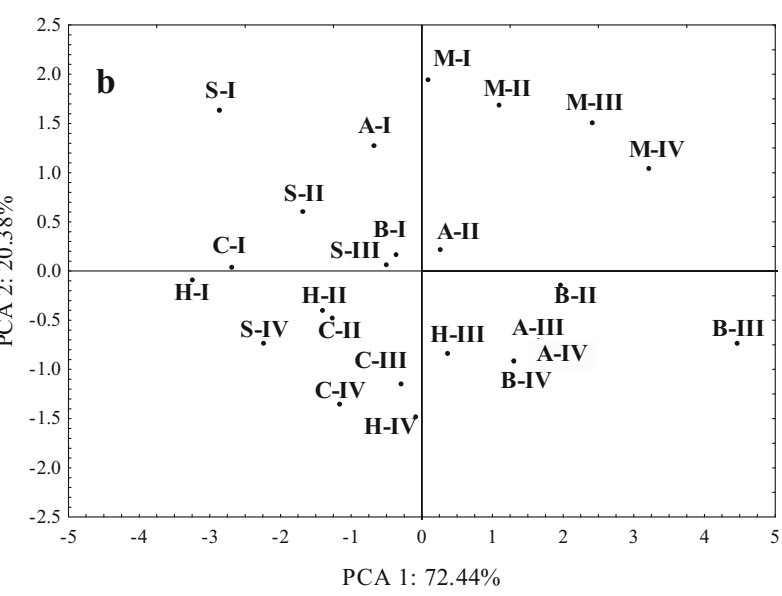

oligotrophic bacteria, Act actinobacteria, Fun fungi, dose of zinc (mg Zn ${ }^{2+} \mathrm{kg}^{-1} \mathrm{DM}$ soil): I 0, II 100, III 300, IV 900; Sorbents: C control, A alginite, B biochar, $\mathrm{S}$ sepiolite, $\mathrm{H}$ halloysite, $\mathrm{M}$ molecular sieve

bacteria $<$ fungi $<$ actinobacteria $<$ oligotrophic bacteria $<$ organotrophic bacteria.

The calculated values of $\mathrm{IF}_{\mathrm{s}}$ indicate that the proliferation of soil-dwelling microorganisms was also influenced by the type of sorbent (Fig. 3). In treatments not contaminated with zinc, the addition of alginate, biochar, and molecular sieve stimulated the proliferation of organotrophic bacteria, copiotrophic bacteria, oligotrophic bacteria, and actinobacteria. The tested sorbents did not stimulate the growth and development of fungi whose $\mathrm{IF}_{\mathrm{s}}$ values ranged from 0.290 (molecular sieve) to 1.022 (halloysite). Alginate, biochar and molecular sieve stimulated the proliferation of organotrophic bacteria, oligotrophic

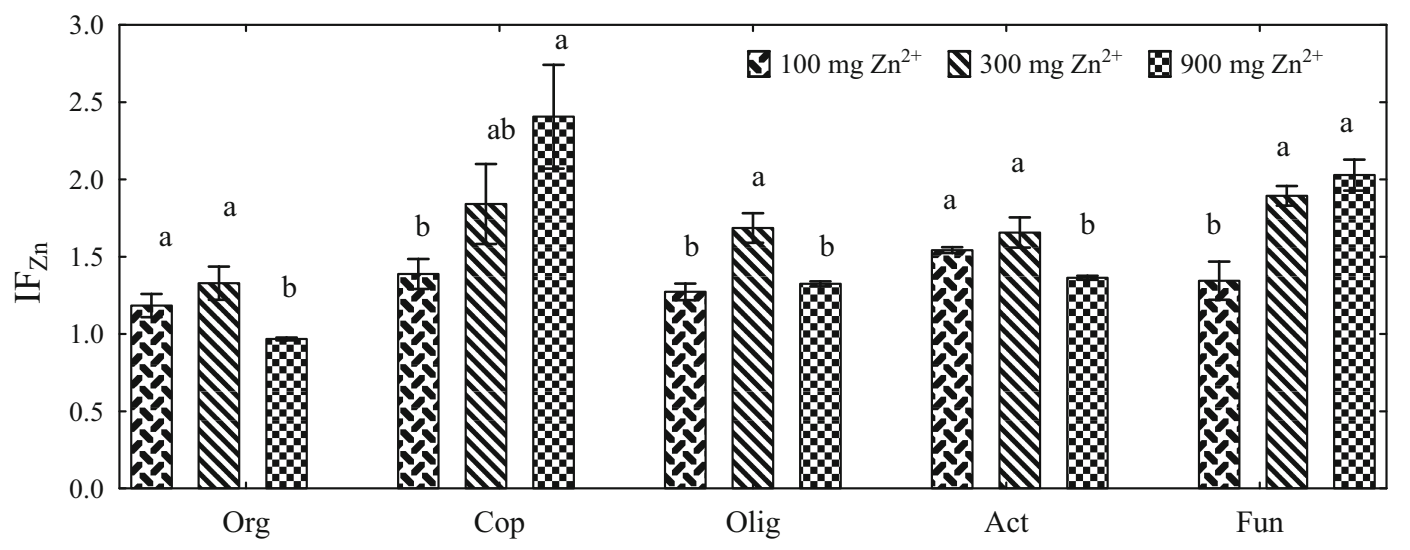

Fig. 2 Influence of zinc $\left(\mathrm{IF}_{\mathrm{Zn}}\right)$ on soil microbial counts in treatments without sorbents (mean values independent of time). Org organotrophic bacteria, Cop copiotrophic bacteria, Olig

oligotrophic bacteria, Act actinobacteria, Fun fungi. Homogeneous groups $(\mathrm{a}, \mathrm{b})$ were created separately for each microbial group $(n=9 ; p=0.05)$ 

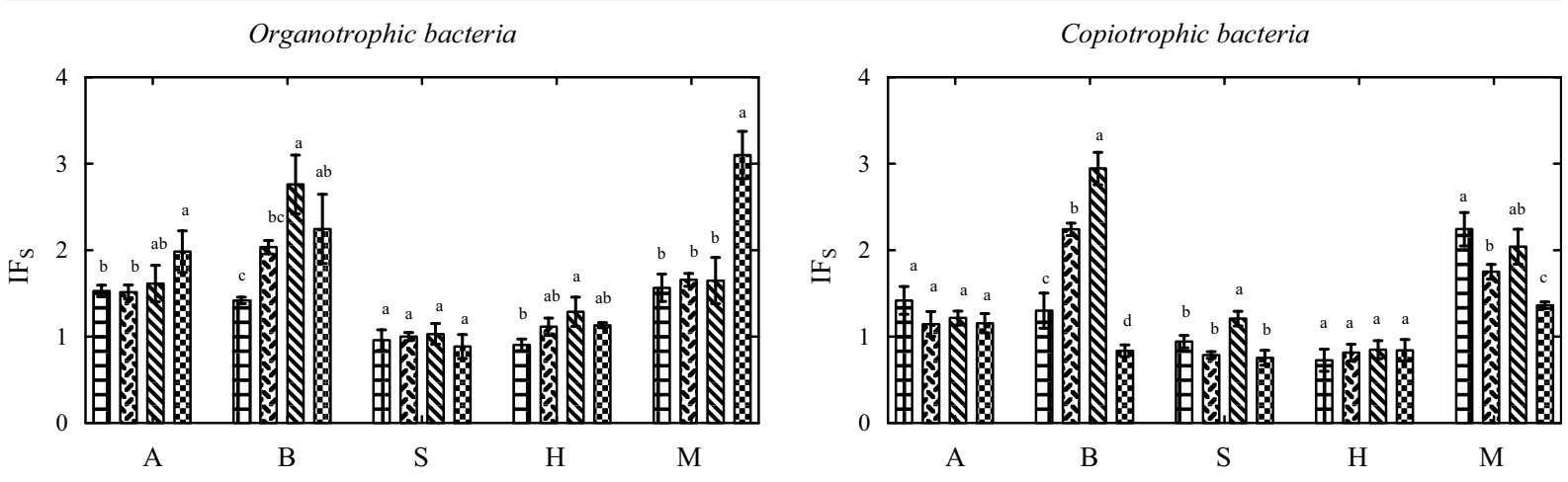

Oligotrophic bacteria
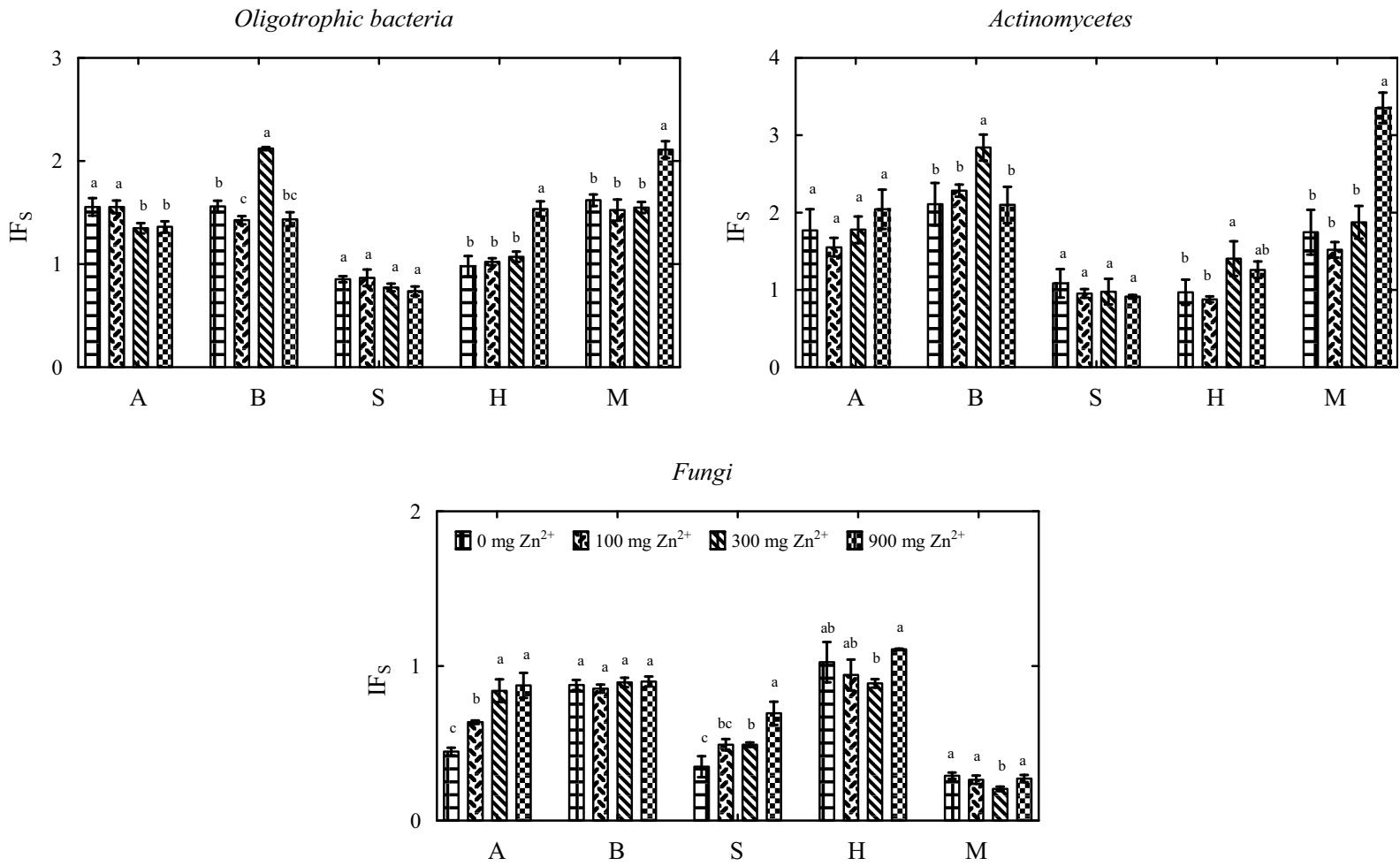

Fig. 3 Influence of sorbents $\left(\mathrm{IF}_{\mathrm{s}}\right)$ on soil microbial counts (mean values independent of time). A alginite, $\mathrm{B}$ biochar, $\mathrm{S}$ sepiolite, $\mathrm{H}$ halloysite, M molecular sieve. Dose of zinc 0, 100, 300, and

bacteria, and actinobacteria. The growth of copiotrophic bacteria was intensified in treatments with the addition of biochar and molecular sieve. The tested sorbents inhibited the proliferation of fungi whose $\mathrm{IF}_{\mathrm{s}}$ values ranged from 0.205 (molecular

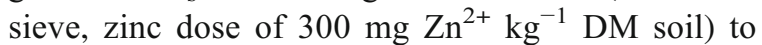
1.105 (halloysite, zinc dose of $900 \mathrm{mg} \mathrm{Zn}^{2+} \mathrm{kg}^{-1} \mathrm{DM}$ soil). Despite the above, the molecular sieve was most effective in stimulating the growth of soildwelling microorganisms.
$900 \mathrm{mg} \mathrm{Zn}^{2+} \mathrm{kg}^{-1} \mathrm{DM}$ soil. Homogeneous groups (a-d) were created separately for each microbial group and each sorbent $(n=$ $12 ; p=0.05)$

Soil contamination with zinc not only led to changes in microbial counts, but also affected the diversity of soil-dwelling microorganisms (Fig. 4). Fungal diversity was most compromised - the value of the EP index determined for fungi decreased from 0.319 to 0.217 under exposure to the highest zinc dose of $900 \mathrm{mg} \mathrm{Zn}^{2+} \mathrm{kg}^{-1} \mathrm{DM}$ soil. The influence of zinc on the EP index of organotrophic bacteria and actinobacteria was more ambiguous. In zinccontaminated treatments, EP values were determined 

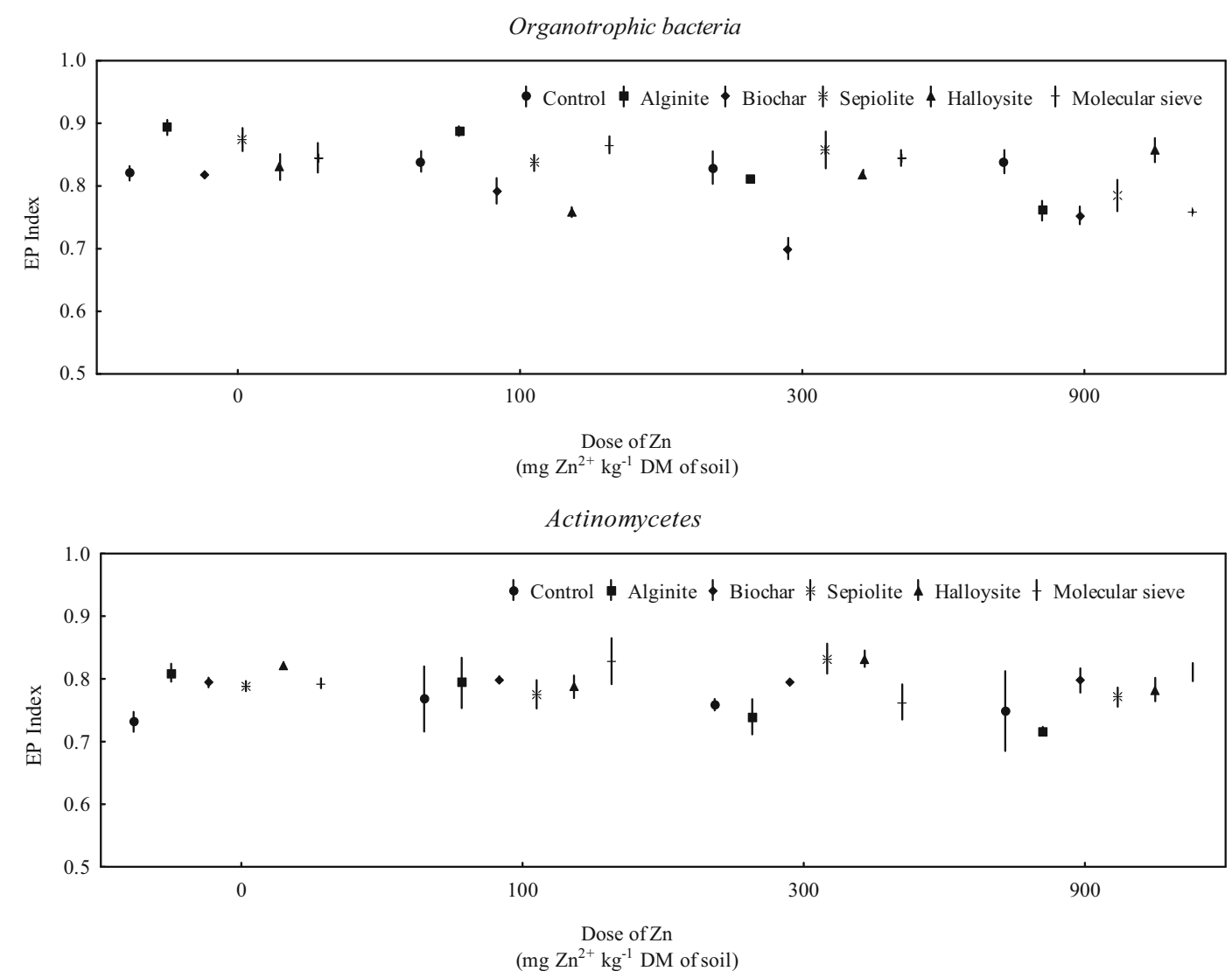

Fungi

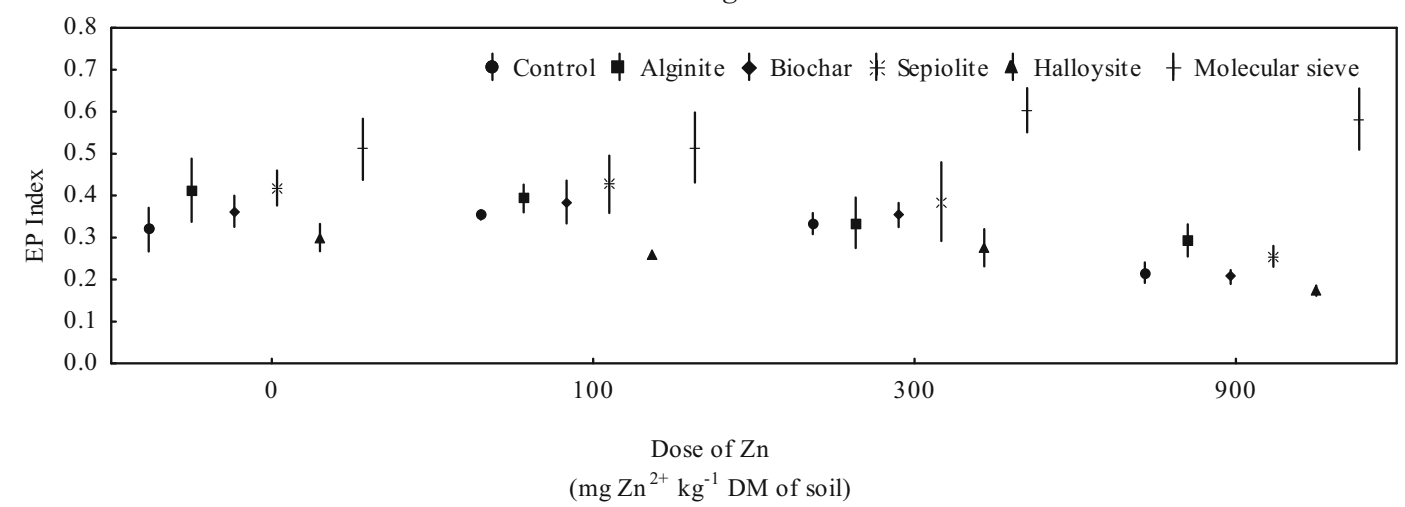

Fig. 4 Ecophysiological diversity (EP) of microorganisms in zinc-contaminated soil. $n=3$; points, mean value; lines, standard deviation

in the range of 0.820 to 0.839 for organotrophic bacteria, and 0.732 to 0.768 for actinobacteria. Sorbents significantly modified the EP index of soil-dwelling microorganisms. In treatments with the highest zinc dose

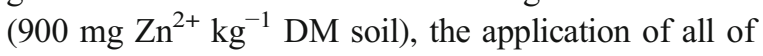
the tested sorbents, excluding calcined halloysite, decreased the EP values of organotrophic bacteria. The EP index of actinobacteria exposed to the same zinc dose increased only in soil treated with the molecular sieve. The remaining sorbents did not induce significant changes in the EP index of actinobacteria after the application of a zinc dose of $900 \mathrm{mg} \mathrm{Zn}^{2+} \mathrm{kg}^{-1}$. Unlike in organotrophic bacteria and actinobacteria, the applied sorbents significantly influenced the EP values of fungi. The molecular sieve increased the EP index of fungi relative to treatments without this sorbent. A reverse 
relationship was noted in treatments with the addition of halloysite. A decrease in the EP index of fungi was noted relative to treatments where sorbents were not applied. The highest EP values were observed in organotrophic bacteria, and the lowest EP values were noted in fungi.

\subsection{Biochemical Properties of Soil}

The biochemical properties of soil are determined by the soil microbiome, and therefore they are reliable indicators of soil contamination, including with zinc. The activity of soil enzymes was influenced mostly by zinc dose and the applied sorbents (Table 2). Zinc dose had the greatest impact on dehydrogenase activity (50.35\%), and the applied sorbent - on urease activity (79.84\%). The greatest variations in catalase activity (17.18\%) were observed between analytical dates.

The evaluated enzymes were divided into three groups based on their responses to the experimental factors. The first group consisted of urease and alkaline phosphatase, the second group included dehydrogenases and catalase, and the third group comprised $\beta$ glucosidase and acid phosphatase (Fig. 5a). The projection of cases revealed that the activity of dehydrogenases and catalase decreased with a rise in zinc contamination levels. Alginate and biochar stimulated the activity of oxidoreductases. The activity of alkaline phosphatase and urease was stimulated by the molecular sieve and alginate. The activity of acid phosphatase and $\beta$-glucosidase was highest in treatments without

Table 2 Percentage contribution of the experimental factors to the observed variation $\left(\eta^{2}\right)$ in enzyme activity in zinc-contaminated soil

\begin{tabular}{lrrrrrr}
\hline Factors & Deh & \multicolumn{1}{l}{ Cat } & Pac & Pal & Ure & Glu \\
\hline Dose of Zn (a) & 50.35 & 37.27 & 21.39 & 32.23 & 4.66 & 22.69 \\
Sorbents (b) & 25.18 & 7.41 & 32.20 & 52.70 & 79.84 & 32.21 \\
Time (c) & 11.08 & 17.18 & 12.47 & 0.18 & 1.11 & 6.87 \\
$\mathrm{a} \cdot \mathrm{b}$ & 6.45 & 13.98 & 21.46 & 7.68 & 11.47 & 19.67 \\
$\mathrm{~b} \cdot \mathrm{c}$ & 0.86 & 3.91 & 0.52 & 0.75 & 0.45 & 6.39 \\
$\mathrm{~b} \cdot \mathrm{c}$ & 3.89 & 5.98 & 5.04 & 1.05 & 1.43 & 3.53 \\
$\mathrm{a} \cdot \mathrm{b} \cdot \mathrm{c}$ & 2.01 & 12.39 & 6.80 & 5.15 & 0.61 & 8.36 \\
Error & 0.18 & 1.88 & 0.12 & 0.26 & 0.43 & 0.28 \\
\hline
\end{tabular}

$Z n$ zinc, Deh dehydrogenases, Cat catalase, $P a c$ acid phosphatase, $P a l$ alkaline phosphatase, Ure urease, Glu $\beta$-glucosidase sorbents and in treatments amended with sepiolite (Fig. 5b).

The values of $\mathrm{IF}_{\mathrm{Zn}}$ confirmed that zinc exerted varied effects on the biochemical properties of soil (Fig. 6). The activity of dehydrogenases, catalase, and acid phosphatase decreased with increasing zinc doses, particularly in treatments with the highest zinc dose $\left(900 \mathrm{mg} \mathrm{Zn}^{2+} \mathrm{kg}^{-1}\right.$ DM soil). The activity of alkaline phosphatase, urease, and $\beta$-glucosidase was stimulated by zinc doses of 100 and $300 \mathrm{Zn}^{2+} \mathrm{kg}^{-1} \mathrm{DM}$ soil. Dehydrogenases were most sensitive to high concentrations of zinc.

In treatments not contaminated with zinc (Fig. 7), alginate and molecular sieve enhanced the activity of urease ( $\mathrm{IF}_{\mathrm{s}}$ of 2.025 and 9.216, respectively) and alkaline phosphatase $\left(\mathrm{IF}_{\mathrm{s}}=1.649\right.$ and 1.484 , respectively). Biochar and sepiolite stimulated the activity of alkaline phosphatase $\left(\mathrm{IF}_{\mathrm{s}}=1.515\right.$ and 1.354 , respectively), and halloysite increased the activity of acid phosphatase $\left(\mathrm{IF}_{\mathrm{S}}=1.254\right)$ and urease $\left(\mathrm{IF}_{\mathrm{S}}=1.308\right)$. The tested sorbents were less effective stimulants of dehydrogenases, catalase, and $\beta$-glucosidase. The activity of dehydrogenases was stimulated only by alginate $\left(\mathrm{IF}_{\mathrm{s}}=1.596\right)$. The values of $\mathrm{IF}_{\mathrm{s}}$ indicate that the tested sorbents exerted varied effects on soil biochemical activity. The molecular sieve stimulated the activity of dehydrogenases, catalase, alkaline phosphatase, and urease. Alginate enhanced the activity of dehydrogenases, alkaline phosphatase, and urease. In treatments contaminated with zinc doses of 300 and $900 \mathrm{mg} \mathrm{Zn}^{2+} \mathrm{kg}^{-1} \mathrm{DM}$ soil, biochar and sepiolite inhibited dehydrogenase activity. Halloysite was an effective stimulant of acid phosphatase, and it also increased the activity of dehydrogenases and urease in treatments contaminated with the highest zinc dose (900 $\mathrm{mg} \mathrm{Zn}^{2+} \mathrm{kg}^{-1} \mathrm{DM}$ soil). None of the sorbents were effective stimulants of $\beta$-glucosidase activity whose $\mathrm{IF}_{\mathrm{s}}$ values ranged from 0.661 (halloysite,

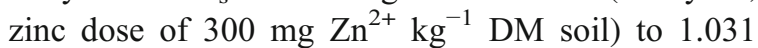

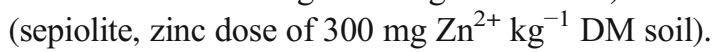

The values of the RS index, calculated based on the BA index, indicate that enzyme activity decreased with a rise in zinc contamination (Fig. 8). In treatments exposed to a zinc dose of

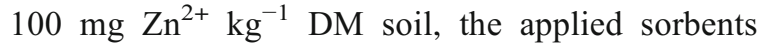
decreased enzyme resistance to zinc. However, the tested remediation agents exerted protective effects in treatments contaminated with zinc doses of 300 and $900 \mathrm{mg} \mathrm{Zn}^{2+} \mathrm{kg}^{-1} \mathrm{DM}$ soil. The molecular sieve was most effective in minimizing the adverse effects of zinc on soil biochemical activity. 


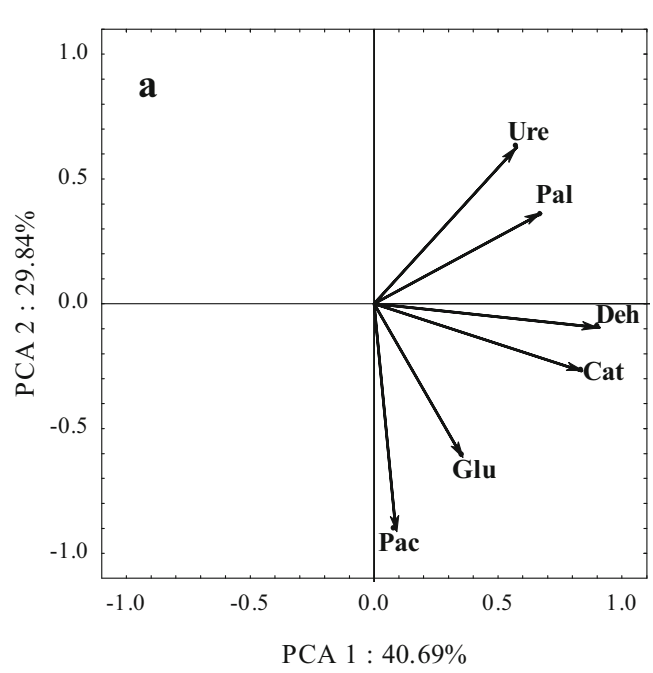

Fig. 5 Enzyme activity in zinc-contaminated soil in principal component analysis (PCA). a Projection of vectors onto a plane describing enzymes activity. b Projection of cases onto the plane. Deh dehydrogenases, Cat catalase, Pac acid phosphatase, Pal

\subsection{Physicochemical and Chemical Properties of Soil}

The results of this study indicate that the application of zinc and sorbents induced changes in the basic physicochemical properties of soil (Table 3). In treatments contaminated with zinc, soil $\mathrm{pH}$ and total exchangeable bases decreased with a rise in zinc dose, which contributed to an increase in hydrolytic acidity. Soil sorption capacity and base saturation decreased in response to high zinc concentrations. In treatments exposed to the highest zinc dose (900 $\mathrm{mg} \mathrm{Zn}^{2+} \mathrm{kg}^{-1} \mathrm{DM}$ soil), soil sorption capacity decreased by $13.5 \%$ and base saturation decreased by $15.8 \%$ relative to the control sample.

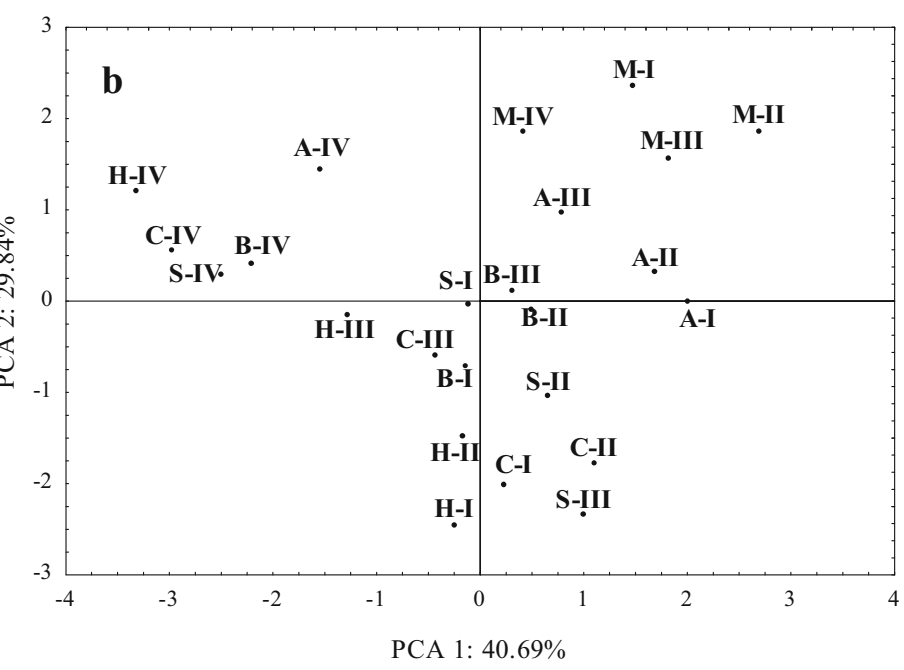

alkaline phosphatase, Ure urease, Glu $\beta$-glucosidase, dose of zinc (mg Zn ${ }^{2+} \mathrm{kg}^{-1} \mathrm{DM}$ soil): I 0, II 100, III 300, IV 900; sorbents: C control, A alginite, $\mathrm{B}$ biochar, $\mathrm{S}$ sepiolite, $\mathrm{H}$ halloysite, $\mathrm{M}$ molecular sieve

The analyzed remediation agents exerted varied effects on the physicochemical properties of soil. Alginate, sepiolite, and molecular sieve significantly increased soil $\mathrm{pH}$ and total exchangeable bases. The remaining sorbents had a minor effect on the evaluated physicochemical parameters of soil. However, hydrolytic acidity decreased in response to all sorbents, excluding halloysite. Alginate, sepiolite, and molecular sieve induced the greatest changes. The tested sorbents increased soil sorption capacity and base saturation relative to treatments without sorbents. The applied sorbents did not decrease the concentrations of bioavailable zinc in soil (Fig. 9). In the most heavily contaminated

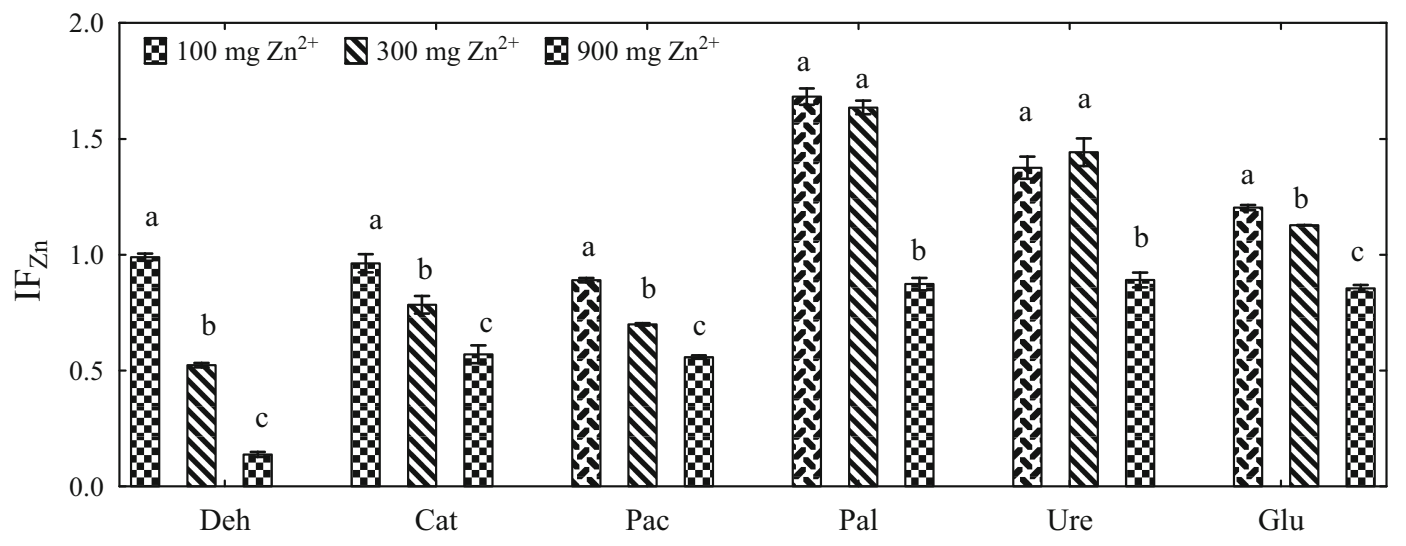

Fig. 6 Influence of zinc $\left(\mathrm{IF}_{\mathrm{Zn}}\right)$ on the activity of soil enzymes in treatments without sorbents (mean values independent of time). Deh dehydrogenases, Cat catalase, Pac acid phosphatase, Pal

alkaline phosphatase, Ure urease, Glu $\beta$-glucosidase. Homogeneous groups $(\mathrm{a}-\mathrm{c})$ were created separately for each enzyme $(n=$ $9 ; p=0.05)$ 

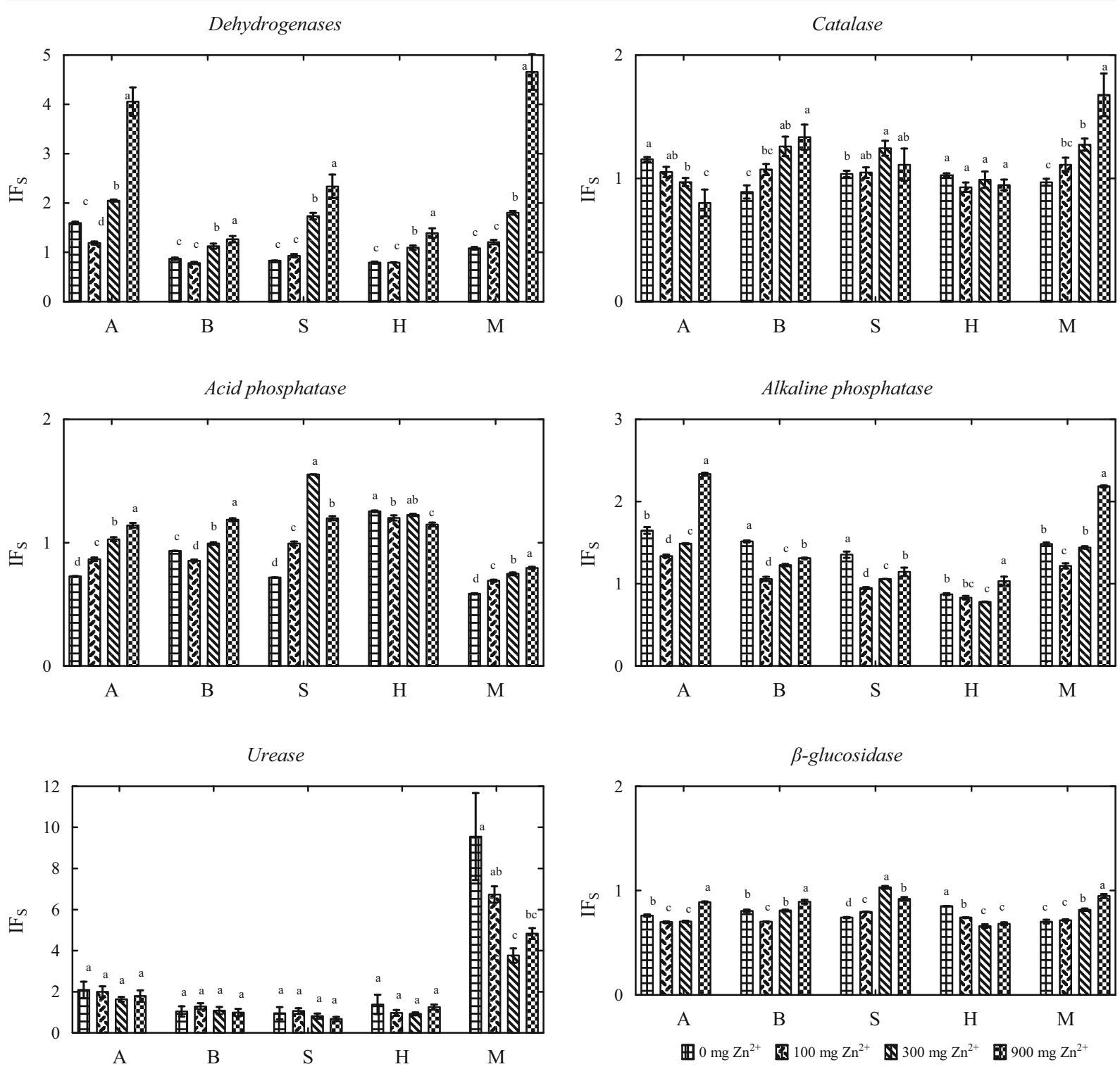

Fig. 7 Influence of sorbents $\left(\mathrm{IF}_{\mathrm{s}}\right)$ on the activity of soil enzymes (mean values independent of time). A alginite, B biochar, S sepiolite, $\mathrm{H}$ halloysite, $\mathrm{M}$ molecular sieve. Dose of zinc 0, 100,

treatments, sorbents increased the content of plantavailable zinc relative to the applied zinc dose. In treatments with a zinc dose of $900 \mathrm{mg} \mathrm{Zn}^{2+} \mathrm{kg}^{-1}$, bioavailable zinc content increased relative to control soil as follows: 1.5 -fold after the application of alginite, 1.4fold after the application of biochar and halloysite, 1.2fold after the application of sepiolite, and 1.6-fold after the application of molecular sieve. The molecular sieve contributed to the highest increase in bioavailable zinc content relative to soil without sorbents.

300 , and $900 \mathrm{mg} \mathrm{Zn}^{2+} \mathrm{kg}^{-1} \mathrm{DM}$ soil. Homogeneous groups (a-d) were created separately for each enzyme and each sorbent $(n=12$; $p=0.05)$

\subsection{Maize Yield}

Zinc contamination induced significant changes in the yield of the aerial parts and roots of maize plants (Fig. 10). In treatments without sorbents, the highest zinc dose (900 $\mathrm{mg} \mathrm{Zn}^{2+} \mathrm{kg}^{-1} \mathrm{DM}$ soil) decreased the yield of aerial plant parts by $69.04 \%$ and root yield - by $35.66 \%$. Sorbents minimized the adverse effects of zinc on maize yield. In treatments contaminated a zinc dose

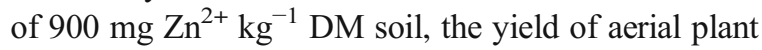




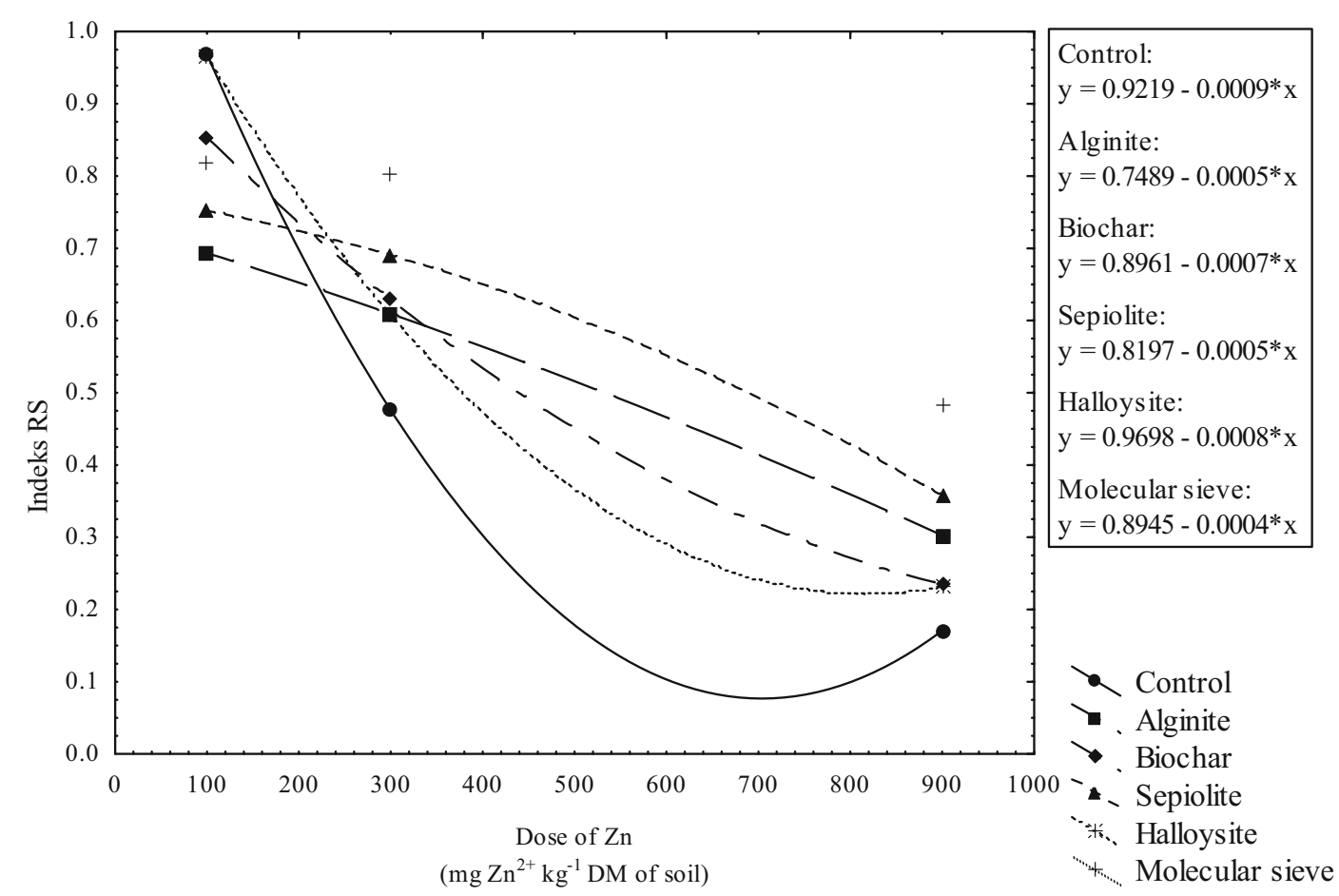

Fig. 8 Soil resistance (RS) to zinc contamination expressed by changes in the values of the soil biochemical quality index (BA)

parts increased by $87.32 \%$ in response to alginate, $47.10 \%$ in response to biochar, $55.80 \%$ in response to sepiolite, $30.80 \%$ in response to halloysite, and $40.58 \%$ in response to the molecular sieve. The analyzed sorbents also contributed to a significant increase in root yield. In treatments with the highest zinc dose, root yield increased 2.2-fold in response to alginate, 2.8-fold in response to biochar, 2.5-fold in response to sepiolite, 1.67 -fold in response to halloysite, and 34-fold in response to the molecular sieve. The molecular sieve decreased zinc uptake by the roots and increased zinc uptake by the aerial parts of maize plants (Table 4). Despite the above, the molecular sieve did not induce changes in zinc accumulation patterns in plants (Fig. 11). The zinc content of plants was similar in treatments without sorbents and in treatments containing the molecular sieve. Zinc concentrations were higher in the roots than in the aerial parts of maize plants (Fig. 10).

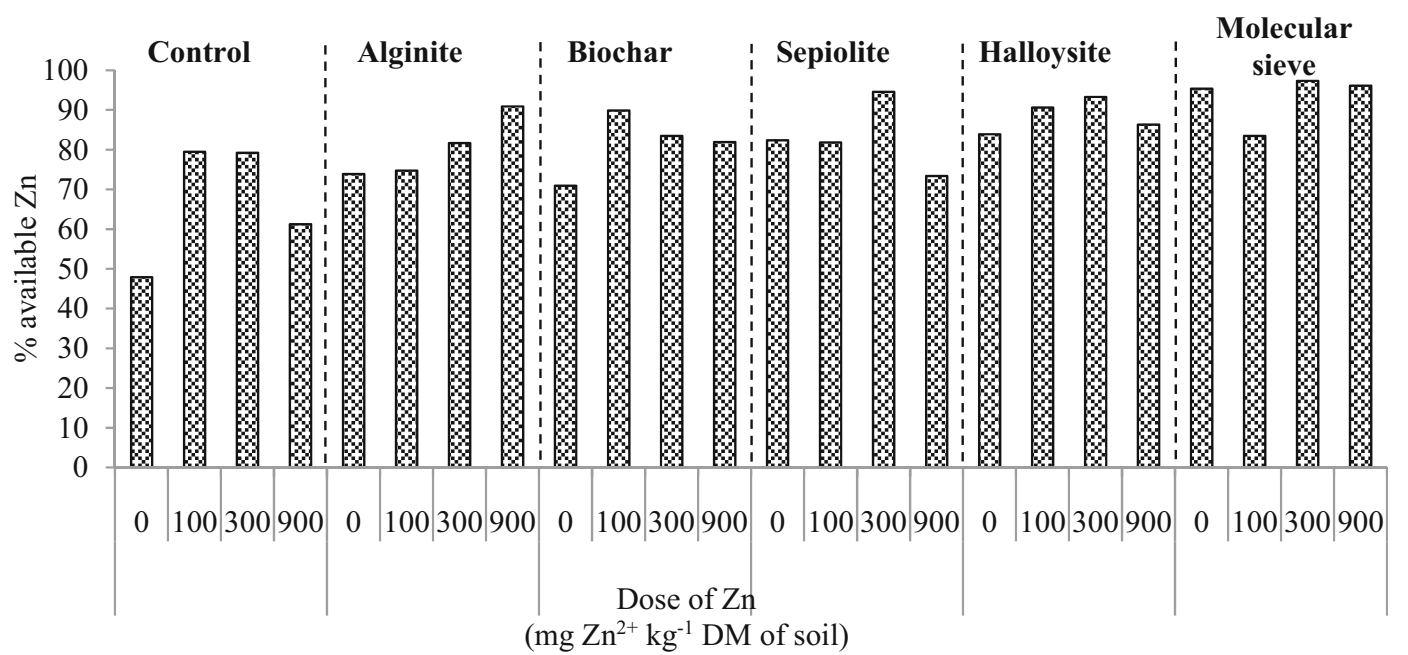

Fig. 9 Percentage content of bioavailable zinc relative to the total zinc content of soil 


\section{Shoots}

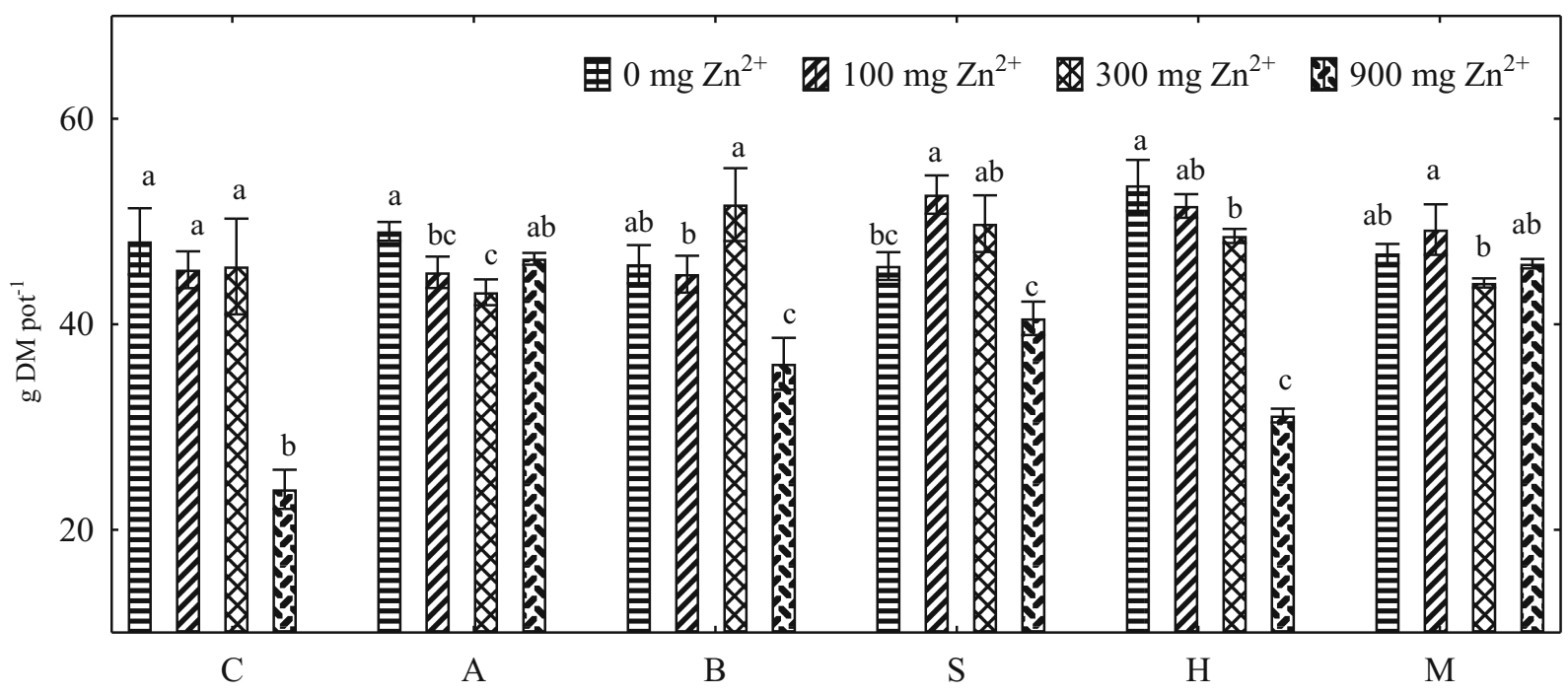

\section{Roots}

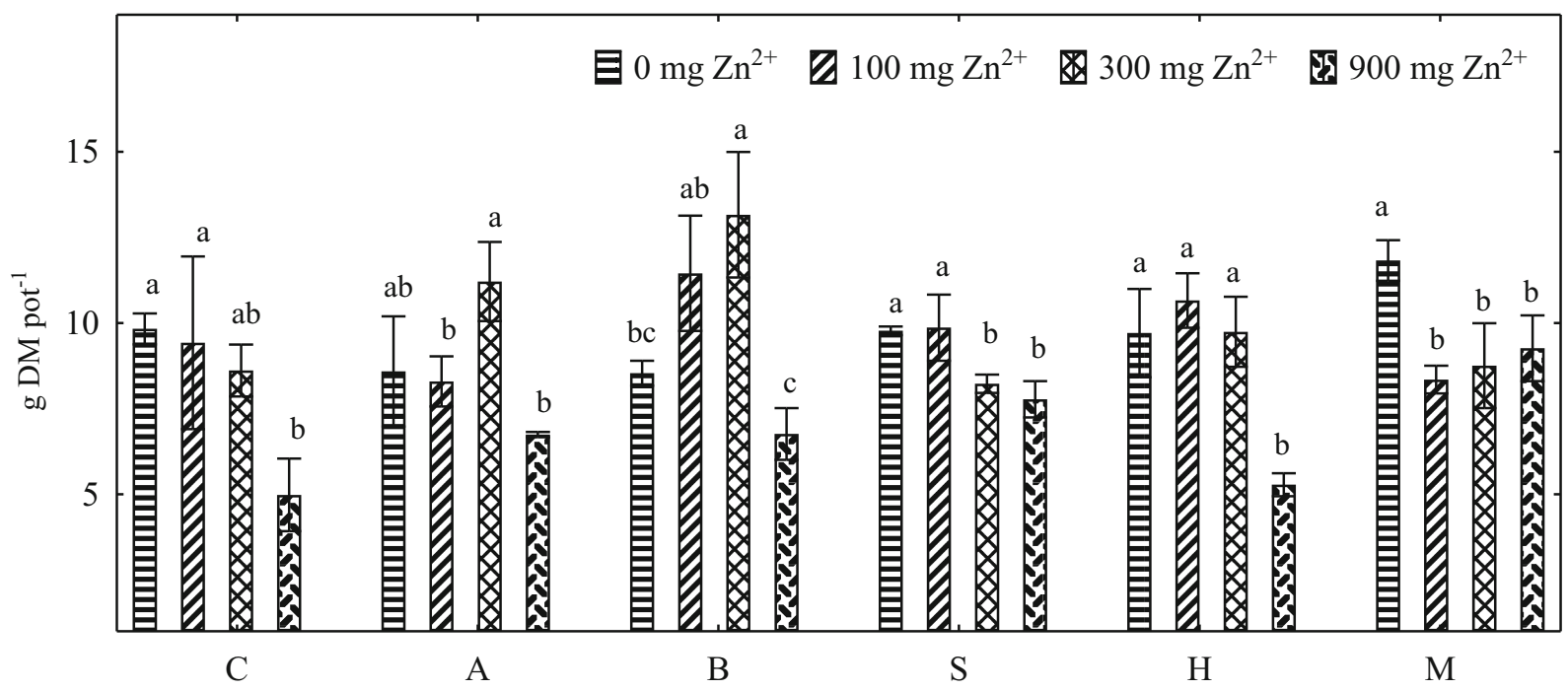

Fig. 10 Dry matter yield of maize $\left(\mathrm{g}_{\text {pot }}{ }^{-1}\right.$ ). C control, A alginite, B biochar, S sepiolite, $\mathrm{H}$ halloysite, M molecular sieve. Homogeneous groups $(\mathrm{a}-\mathrm{c})$ were created separately for each sorbent $(n=12 ; p=0.05)$

Plants exposed to various zinc doses did not differ in their zinc accumulation patterns.

\section{Discussion}

The soil microbiome can be modified under exposure to external factors, including substances with toxic effects. In the present study, zinc intensified the proliferation of soil-dwelling microorganisms. Microbial growth was determined by both the zinc dose and the date of analysis. The stimulatory effects of zinc on the abundance of soil microorganism have also been observed by other authors Wyszkowska et al. (2013). However, excessive zinc concentrations (1200 $\mathrm{mg} \mathrm{Zn}^{2+} \mathrm{kg}^{-1} \mathrm{DM}$ soil) can disrupt the soil microbiome and reduce microbial abundance (Wyszkowska et al. 2016). According to Aiju et al. (2013), the zinc content of soil of 74.33 to 
Table 3 Physicochemical properties of soil contaminated with zinc and amended with sorbents

\begin{tabular}{|c|c|c|c|c|c|c|}
\hline $\begin{array}{l}\text { Dose of } \mathrm{Zn} \\
\left(\mathrm{mg} \mathrm{Zn}^{2+} \mathrm{kg}^{-1}\right)\end{array}$ & $\begin{array}{l}\text { Control } \\
\mathrm{pH}_{\mathrm{KCl}}\end{array}$ & Alginite & Biochar & Sepiolite & Halloysite & Molecular sieve \\
\hline 0 & $6.30^{\mathrm{a}}$ & $7.13^{\mathrm{a}}$ & $6.65^{\mathrm{a}}$ & $7.23^{\mathrm{a}}$ & $6.47^{\mathrm{a}}$ & $7.42^{\mathrm{a}}$ \\
\hline 100 & $6.20^{\mathrm{b}}$ & $7.10^{\mathrm{ab}}$ & $6.63^{\mathrm{a}}$ & $7.00^{\mathrm{b}}$ & $6.45^{\mathrm{ab}}$ & $7.35^{\mathrm{b}}$ \\
\hline 300 & $6.13^{\mathrm{c}}$ & $7.02^{\mathrm{b}}$ & $6.45^{\mathrm{b}}$ & $6.90^{\mathrm{c}}$ & $6.37^{\mathrm{b}}$ & $7.32^{\mathrm{b}}$ \\
\hline \multirow[t]{2}{*}{900} & $5.77^{\mathrm{d}}$ & $6.87^{\mathrm{c}}$ & $6.30^{\mathrm{c}}$ & $6.60^{\mathrm{d}}$ & $5.95^{\mathrm{c}}$ & $7.15^{\mathrm{c}}$ \\
\hline & \multicolumn{6}{|c|}{ Hydrolytic acidity (HAC) $\mathrm{mM}(+) \mathrm{kg}^{-1} \mathrm{DM}$ soil } \\
\hline 0 & $14.50^{\mathrm{b}}$ & $7.50^{\mathrm{c}}$ & $12.25^{\mathrm{c}}$ & $9.00^{\mathrm{c}}$ & $15.00^{\mathrm{c}}$ & $8.50^{\mathrm{b}}$ \\
\hline 100 & $15.00^{\mathrm{b}}$ & $9.00^{\mathrm{b}}$ & $12.75^{\mathrm{c}}$ & $10.25^{\mathrm{bc}}$ & $16.00^{\mathrm{bc}}$ & $9.50^{\mathrm{ab}}$ \\
\hline 300 & $15.50^{\mathrm{b}}$ & $9.50^{\mathrm{b}}$ & $14.50^{\mathrm{b}}$ & $11.50^{\mathrm{ab}}$ & $16.50^{\mathrm{b}}$ & $10.00^{\mathrm{ab}}$ \\
\hline \multirow[t]{2}{*}{900} & $19.00^{\mathrm{a}}$ & $11.25^{\mathrm{a}}$ & $16.25^{\mathrm{a}}$ & $12.75^{\mathrm{a}}$ & $19.50^{\mathrm{a}}$ & $11.00^{\mathrm{a}}$ \\
\hline & \multicolumn{6}{|c|}{ Total exchangeable bases (TEB) $\mathrm{mM}(+) \mathrm{kg}^{-1} \mathrm{DM}$ soil } \\
\hline 0 & $46.00^{\mathrm{a}}$ & $125.33^{\mathrm{a}}$ & $50.67^{\mathrm{a}}$ & $100.67^{\mathrm{b}}$ & $50.00^{\mathrm{a}}$ & $122.67^{\mathrm{a}}$ \\
\hline 100 & $40.67^{\mathrm{b}}$ & $123.33^{\mathrm{a}}$ & $47.33^{\mathrm{b}}$ & $105.33^{\mathrm{a}}$ & $44.00^{\mathrm{b}}$ & $118.67^{\mathrm{b}}$ \\
\hline 300 & $38.67^{\mathrm{b}}$ & $120.67^{\mathrm{a}}$ & $46.67^{\mathrm{b}}$ & $102.67^{\mathrm{ab}}$ & $40.00^{\mathrm{c}}$ & $117.33^{\mathrm{b}}$ \\
\hline \multirow[t]{2}{*}{900} & $33.33^{\mathrm{c}}$ & $114.00^{\mathrm{b}}$ & $44.00^{\mathrm{c}}$ & $92.67^{\mathrm{c}}$ & $30.67^{\mathrm{d}}$ & $113.33^{\mathrm{c}}$ \\
\hline & \multicolumn{6}{|c|}{ Cation exchange capacity (CEC) $\mathrm{mM}(+) \mathrm{kg}^{-1} \mathrm{DM}$ soil } \\
\hline 0 & $60.50^{\mathrm{a}}$ & $132.83^{\mathrm{a}}$ & $62.92^{\mathrm{a}}$ & $109.67^{\mathrm{b}}$ & $65.00^{\mathrm{a}}$ & $131.17^{\mathrm{a}}$ \\
\hline 100 & $55.67^{\mathrm{b}}$ & $132.33^{\mathrm{a}}$ & $60.08^{\mathrm{a}}$ & $115.58^{\mathrm{a}}$ & $60.00^{\mathrm{b}}$ & $128.17^{\mathrm{ab}}$ \\
\hline 300 & $54.17^{b c}$ & $130.17^{\mathrm{ab}}$ & $61.17^{\mathrm{a}}$ & $114.17^{\mathrm{a}}$ & $56.50^{\mathrm{c}}$ & $127.33^{\mathrm{ab}}$ \\
\hline \multirow[t]{2}{*}{900} & $52.33^{\mathrm{c}}$ & $125.25^{\mathrm{b}}$ & $60.25^{\mathrm{a}}$ & $105.42^{\mathrm{b}}$ & $50.17^{\mathrm{d}}$ & $124.33^{\mathrm{b}}$ \\
\hline & \multicolumn{6}{|c|}{ Base saturation (BS) \% } \\
\hline 0 & $76.04^{\mathrm{a}}$ & $94.35^{\mathrm{a}}$ & $80.53^{\mathrm{a}}$ & $91.79^{\mathrm{a}}$ & $76.92^{\mathrm{a}}$ & $93.52^{\mathrm{a}}$ \\
\hline 100 & $73.05^{\mathrm{ab}}$ & $93.20^{\mathrm{ab}}$ & $78.77^{\mathrm{a}}$ & $91.13^{\mathrm{a}}$ & $73.34^{\mathrm{b}}$ & $92.59^{\mathrm{ab}}$ \\
\hline 300 & $71.34^{\mathrm{b}}$ & $92.70^{\mathrm{b}}$ & $76.30^{\mathrm{b}}$ & $89.93^{\mathrm{b}}$ & $70.80^{\mathrm{c}}$ & $92.15^{\mathrm{ab}}$ \\
\hline 900 & $63.69^{\mathrm{c}}$ & $91.02^{\mathrm{c}}$ & $73.03^{\mathrm{c}}$ & $87.91^{\mathrm{c}}$ & $61.12^{\mathrm{d}}$ & $91.16^{\mathrm{b}}$ \\
\hline
\end{tabular}

$Z n$ zinc. Homogeneous groups (a-d) were created separately for the physicochemical properties of soil and the applied sorbents $(n=12 ; p=$ $0.05)$

$127.20 \mathrm{mg} \mathrm{kg}^{-1}$ may lead to adverse changes in the microbiological parameters of soil ecosystems.
Kouchou et al. (2017) noted a decrease in the counts of fungi and actinobacteria and an increase in bacterial

Table 4 Zinc content of maize plants in treatments without sorbents and in treatments where a molecular sieve was applied

\begin{tabular}{|c|c|c|c|c|}
\hline & \multirow[t]{2}{*}{ Dose of $\mathrm{Zn}\left(\mathrm{mg} \mathrm{Zn}{ }^{2+} \mathrm{kg}^{-1}\right)$} & \multirow{2}{*}{$\begin{array}{l}\text { Control } \\
\mathrm{mg} \mathrm{Zn}^{2+} \mathrm{kg}^{-1}\end{array}$} & \multicolumn{2}{|c|}{ Molecular sieve } \\
\hline & & & & Decrease $(\%)$ \\
\hline \multirow[t]{4}{*}{ Shoots } & 0 & 23.00 & 21.00 & 8.70 \\
\hline & 100 & 106.40 & 40.80 & 61.65 \\
\hline & 300 & 293.00 & 59.20 & 79.80 \\
\hline & 900 & 1416.00 & 107.20 & 92.43 \\
\hline \multirow[t]{4}{*}{ Roots } & 0 & 63.60 & 61.00 & 4.09 \\
\hline & 100 & 299.00 & 72.00 & 75.92 \\
\hline & 300 & 1148.00 & 156.00 & 86.41 \\
\hline & 900 & 5030.00 & 392.00 & 92.21 \\
\hline
\end{tabular}




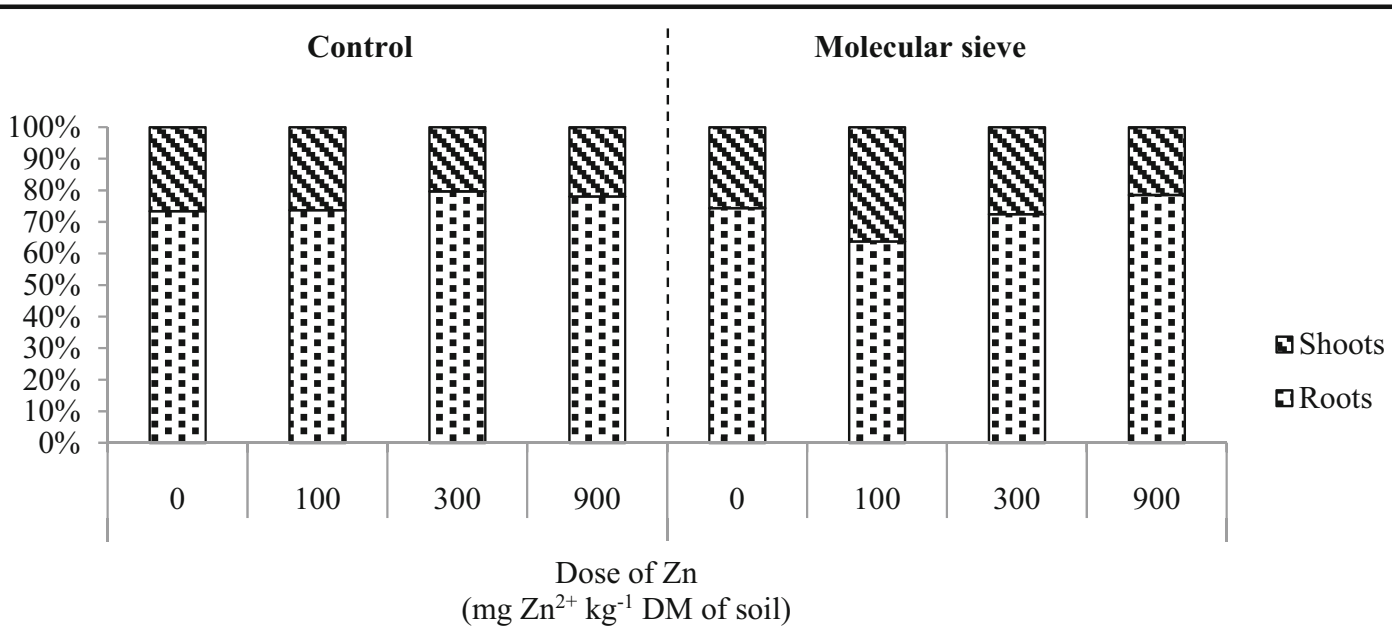

Fig. 11 Zinc distribution in maize dry matter (\%)

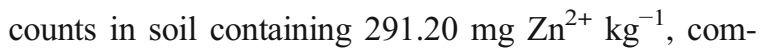
pared with control soil. In the present study, the highest zinc dose (900 mg Zn ${ }^{2+} \mathrm{kg}^{-1}$ DM soil) exerted a toxic effect on organotrophic bacteria and decreased the counts of the remaining microbial groups in treatments contaminated with zinc doses of 100 and

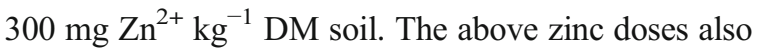
induced changes in the EP index of soil-dwelling microorganisms. Zinc applied at the highest dose (900 mg Z Zn ${ }^{2+} \mathrm{kg}^{-1}$ ) could exert a toxic effect on soildwelling microorganisms, which was reflected in changes in microbial diversity. Excessive zinc concentrations in soil made it impossible for the microorganisms to adapt to the existing conditions. When present in high concentrations, the heavy metal could penetrate the cell membranes of microorganisms, leading to changes in the structure and function of cell organelles, followed by cell death. The observed changes in biodiversity could also result from microbial succession. The soil environment was dominated by microbial species resistant to high zinc concentrations, which eliminated the remaining microorganisms. The negative effect of zinc on soil biological activity was also observed by Epelde et al. (2010) who found that a zinc dose of $1000 \mathrm{mg} \mathrm{kg}^{-1}$ inhibited the proliferation of total bacteria and nitrifying bacteria. Other authors also reported a decrease in the counts of organotrophic bacteria, bacteria of the genus Azotobacter, actinobacteria, and fungi in soil contaminated with zinc doses of 150 to $1200 \mathrm{mg} \mathrm{Zn}^{2+} \mathrm{kg}^{-1} \mathrm{DM}$ soil (Wyszkowska et al. 2015). According to Macdonald et al. (2008), longterm application of heavy metals, including zinc, may lead to changes in the proliferation and structure of microorganisms. Zinc doses of $150-450 \mathrm{mg} \mathrm{Zn}^{2+} \mathrm{kg}^{-1}$ significantly affected the structure of microbial communities, in particular fungi.

Changes in the microbiological properties of soil also disrupt soil biochemistry and decrease enzyme activity (Borowik et al. 2014; Wieczorek et al. 2014; Wyszkowska et al. 2016; Yang et al. 2006). Soil enzymes rapidly respond to contamination, and they are good indicators of the changes induced by xenobiotics. In the current study, zinc inhibited the activity of all analyzed soil enzymes (dehydrogenases, catalase, urease, acid phosphatase, alkaline phosphatase, $\beta$-glucosidase). The highest zinc dose (900 $\mathrm{mg} \mathrm{Zn}^{2+} \mathrm{kg}^{-1} \mathrm{DM}$ soil) had a particularly inhibitory influence on enzyme activity. Similar results were reported in a study evaluating the influence of zinc doses of 150,300,600, and $1200 \mathrm{mg} \mathrm{Zn}^{2+} \mathrm{kg}^{-1} \mathrm{DM}$ soil on the activity of dehydrogenases, urease, acid, and alkaline phosphatase (Boros et al. 2011). The cited authors observed that enzyme activity decreased with increasing zinc levels. According to Borowik et al. (2014), zinc doses of 300 to

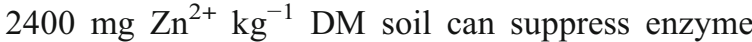
activity in soil. In the work of Kucharski et al. (2011), soil enzymes were arranged in the following order based on their sensitivity to zinc contamination: arylsulfatase $>$ dehydrogenases $>$ acid phosphatase $>$ urease $>\beta$ glucosidase.

Excess zinc can also compromise plant growth and development. In our study, zinc doses of 100 to

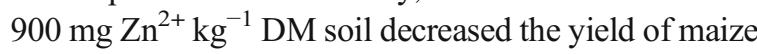
roots and aerial parts.

Substances with soil remediation potential are increasingly used to limit the negative consequences of 
soil contamination with trace elements. These substances decrease the mobility of heavy elements by modifying soil properties such as $\mathrm{pH}$, content of clay minerals and organic matter, cation-exchange capacity, and soil type (Bradl 2004). Other remediation substances promote microbial growth, intensify the biological activity of soil and, consequently, improve soil fertility. In our study, the tested sorbents, in particular alginate and biochar, contributed to the proliferation of organotrophic bacteria, oligotrophic bacteria, copiotrophic bacteria, and actinobacteria. Fungal counts decreased in response to the applied soil remediation agents. The application of sorbents could lead to the immobilization of soil microorganisms, thus inhibiting their proliferation and soil enzymatic activity. The presence of mutual interactions between soil-dwelling microorganisms and biochar was reported by Lehmann and Rondon (2006). Biochar can modify habitat conditions, whereas microorganisms can alter the quantity and properties of biochar. Biochar is characterized by high adsorption capacity (Liang et al. 2006) and a large specific surface area which creates supportive conditions for the immobilization of soil microorganisms (Lehmann et al. 2011). In treatments not contaminated with zinc, the application of biochar increased the EP values of microorganisms. In a study by Steiner et al. (2008), biochar also stimulated the soil microbiome by increasing microbial biomass and microbial activity assessed based on microbial respiration. Biochar increases the bioavailability of soil nutrients and soil $\mathrm{pH}$, which not only contributes to crop yields, but also enables crop production in previously degraded areas (Lehmann and Rondon 2006). In a study evaluating the influence of sepiolite on the soil environment, the analyzed mineral stimulated the proliferation of bacteria and actinobacteria (Sun et al. 2013). In our study, sepiolite did not induce significant changes in the counts of the analyzed microbial groups. Calcined halloysite was not highly effective in improving the microbiological properties of soil. In the work of Wyszkowska et al. (2015), cellulose and fermented bark alleviated the negative effects of zinc on the abundance of Azotobacter bacteria, organotrophic bacteria, and actinobacteria, whereas keratin stimulated fungal growth.

The analysis of enzyme activity in soil also revealed that the applied sorbents minimized the toxic effects of zinc. The evaluated sorbents stimulated the activity of dehydrogenases and catalase which are good indicators of soil microbial activity. In treatments remedied with alginate, the above effects can be attributed to increased organic matter content (Sheng et al. 2004). According to Moreno et al. (2009), enzyme activity is less compromised by zinc in soils with higher organic matter content. Extracellular enzymes are immobilized or form complexes with organic matter and exert protective effects (Kizllkaya et al. 2004). The addition of organic matter to soil stimulates microbial proliferation and increases the biodiversity and activity of enzymes, thus minimizing the adverse effects of zinc (Strachel et al. 2017). Organic matter contains humic substances which play an important role in the environment due to their affinity for soil contaminants (Szabó 2004). Sheng et al. (2004) demonstrated that algae and algal derivatives were effective in decreasing the bioavailability of heavy metals. These effects can be attributed to the functional groups of cell wall polysaccharides. In the work of Tica et al. (2011), an alginate-based substance with high adsorption capacity increased soil $\mathrm{pH}$. Humic substances also increase heavy metal uptake by plants, which is an important consideration in the process of soil phytoremediation. Humic substances and heavy metals form stable complexes, which decreases the mobility of toxic compounds in the soil solution (Halim et al. 2003). In a study by Boros et al. (2011), cellulose and fermented bark stimulated enzyme activity in soil, whereas keratin inhibited the activity of all evaluated enzymes (dehydrogenase, urease, acid, and alkaline phosphatase) and did not alleviate the toxic effects of zinc. In the current study, calcined halloysite stimulated catalase activity. According to Zhai et al. (2010), halloysite contributed to enzyme stability under adverse environmental conditions. Similarly to sepiolite, halloysite is a clay mineral with a large specific surface area which effective absorbs pollutants, including heavy metals (Wu et al. 2016). Halloysite binds trace elements through cation exchange or the formation of surface complexes (Yuan et al. 2015). In addition, materials with high adsorption capacity regulate the microbiological and biochemical properties of soil. According to Lehmann et al. (2011), these substances contribute to the retention of water and nutrients in soil and immobilize microorganisms on their surface. In the work of Sun et al. (2016), bentonite, which is also a clay mineral, exerted protective effects on the soil microbiome and soil enzymes. Bentonite increased the counts of actinobacteria and stimulated catalase activity. In our study, sepiolite induced changes in the activity of alkaline phosphatase and $\beta$-glucosidase. The beneficial 
effects of sepiolite were also reported in a study by Sun et al. (2013) where this mineral enhanced the activity of urease and invertase. Sepiolite can also contribute to increasing soil respiration and the activity of dehydrogenase and alkaline phosphatase (Abad-Valle et al. 2016). Sepiolite immobilizes heavy metals, including zinc, by replacing magnesium ions on the boundaries of octahedral magnesium layers in the substrate (De Lima et al. 2017). In our study, the molecular sieve induced the greatest increase in soil resistance (RS) to zinc, determined based on the BA index. These changes were most pronounced in treatments contaminated with the highest zinc dose (900 $\mathrm{Zn}^{2+} \mathrm{kg}^{-1}$ soil DM). According to Brach et al. (2017), the presence of nanopores in the molecular sieve supports interactions with the ions and molecules of chemical compounds. The above mechanism could be responsible for the observed increase in the counts of bacteria and actinobacteria and enzyme activity. These observations also suggest that substances with a large specific surface area exert protective effects by immobilizing microorganisms and enzymes on their surface.

Changes in the microbiological properties of soil and enzyme activity influence the rate of metabolic processes and, consequently, the physicochemical properties of soil. In our study, the applied sorbents did not decrease the content of bioavailable zinc relative to total zinc concentration in soil. It was found that the molecular sieve decreased zinc uptake by the roots and increased zinc uptake by the aerial parts of maize plants. The tested sorbents increased maize yield, in particular in the most highly contaminated treatments. Our results suggest that the content of bioavailable zinc in soil was significantly modified by nutrient cycling and root secretions. The analyzed soil remediation substances minimized the toxic effects of zinc mainly by promoting the growth of soil-dwelling microorganisms, including organotrophic bacteria, oligotrophic bacteria, and actinobacteria, and by stimulating most soil enzymes, which contributed to an increase in maize yield.

\section{Conclusions}

Increasing levels of environmental pollution prompt the search for new solutions to guarantee global food security. In the described experiment, high zinc doses deteriorated the soil environment by decreasing the counts and biodiversity of microorganisms and disrupting biochemical processes in soil. Zinc had an adverse effect on the growth and development of maize, and it decreased the yield of aerial plant parts. Remediation substances capable of absorbing pollutants were applied to limit the adverse influence of zinc on the soil environment. The tested sorbents generally minimized the toxic effects of zinc on soil microorganisms and enzymes. The analyzed substances also induced changes in the microbiological diversity of soil. The evaluated sorbents did not limit the bioavailability of zinc in soil, but decreased the accumulation of zinc in maize plants. Our findings indicate that not all of the tested sorbents can be effectively used to remediate zinc-contaminated soil. The greatest increase in soil fertility was observed under the influence of alginate, biochar, and molecular sieve. The molecular sieve emerged as the most effective substance for the remediation of soil contaminated with zinc.

Funding InformationScientific research was financed by the Ministry of Science and Higher Education funds for statutory activity.

Open Access This article is distributed under the terms of the Creative Commons Attribution 4.0 International License (http:// creativecommons.org/licenses/by/4.0/), which permits unrestricted use, distribution, and reproduction in any medium, provided you give appropriate credit to the original author(s) and the source, provide a link to the Creative Commons license, and indicate if changes were made.

\section{References}

Abad-Valle, P., Álvarez-Ayuso, E., Murciego, A., \& Pellitero, E. (2016). Assessment of the use of sepiolite amendment to restore heavy metal polluted mine soil. Geoderma, 280, 5766.

Aiju, L., Honghai, W., Peiling, G., \& Hong-zhi, X. (2013). Chemical fraction on $\mathrm{Cu}$ and $\mathrm{Zn}$ their impacts on microbial properties in slightly contaminated soils. International Journal of Agricultural Research Innovation \& Technology, 3(1), 20-25.

Aydinalp, C., \& Marinova, S. (2003). Distribution and forms of heavy metals in some agricultural soils. Polish Journal of Environmental Studies, 12, 629-633.

Boros, E., Baćmaga, M., Kucharski, J., \& Wyszkowska, J. (2011). The usefulness of organic substances and plant growth in neutralizing the effects of zinc on the biochemical properties of soil. Fresenius Environmental Bulletin, 20(12), 31013109 .

Borowik, A., Wyszkowska, J., Kucharski, J., Baćmaga, M., Boros-Lajszner, E., \& Tomkiel, M. (2014). Sensitivity of soil enzymes to excessive zinc concentrations. Journal of Elementology, 19(3), 637-648. 
Borowik, A., Wyszkowska, J., \& Wyszkowski, M. (2017). Resistance of aerobic microorganisms and soil enzyme response to soil contamination with Ekodiesel Ultra fuel. Environmental Science and Pollution Research, 24, 2434624363.

Brach, S., Dormieux, L., Kondo, D., \& Vairo, G. (2017). Strength properties of nanoporous materials: a 3-layered based nonlinear homogenization approach with interface effects. International Journal of Engineering Science, 115, 28-42.

Bradl, H. B. (2004). Adsorption of heavy metal ions on soils and soils constituents. Journal of Colloid and Interface Science, 277(1), 1-18.

De Leij, F. A. A. M., Whipps, J. M., \& Lynch, J. M. (1993). The use of colony development for the characterization of bacterial communities in soil and on roots. Microbial Ecology, 27, 81-97.

De Lima, J. A., Camilo, F. F., Faez, R., \& Cruz, S. A. (2017). A new approach to sepiolite dispersion by treatment with ionic liquids. Applied Clay Science, 143, 234-240.

Epelde, L., Becerril, J. M., Kowalchuk, G. A., Deng, Y., Zhou, J., \& Garbisu, C. (2010). Impact of metal pollution and Thlaspi caerulescens growth on soil microbial communities. Applied and Environmental Microbiology, 76(23), 7843-7853.

Halim, M., Conte, P., \& Piccolo, A. (2003). Potential availability of heavy metals to phytoextraction from contaminated soils induced by exogenous humic substances. Chemosphere, 52(1), 265-275.

Harris D.C. (2006). Quantitative chemical analysis. Michelson Laboratory Chine Lake USA. WH Freeman and Company 7th edition, 1008.

Kaczyńska, G., Borowik, A., \& Wyszkowska, J. (2015). Soil dehydrogenases as an indicator of contamination of the environment with petroleum products. Water, Air, \& Soil Pollution, 226(11), 372.

Khalid, S., Shahid, M., Nabeel, N. K., Murtaza, B., Bibi, I., \& Dumat, C. (2017). A comparison of technologies for remediation of heavy metal contaminated soils. Journal of Geochemical Exploration, 182(Part B), 247-268.

Kızılkaya, R., Așkın, T., Bayraklı, B., \& Sağlam, M. (2004). Microbiological characteristics of soils contaminated with heavy metals. European Journal of Soil Biology, 40(2), 95102.

Kouchou, A., Rais, N., Elsass, F., Duplay, J., Fahli, N., \& Ghachtouli, N. E. L. (2017). Effects of long-term heavy metals contamination on soil microbial characteristics in calcareous agricultural lands (Saiss plain, North Morocco). Journal of Materials and Environmental Sciences, 8(2), 691695.

Krężel, A., \& Maret, W. (2016). The biological inorganic chemistry of zinc ions. Archives of Biochemistry and Biophysics, 611, 3-19.

Kucharski, J., Wieczorek, K., \& Wyszkowska, J. (2011). Changes in the enzymatic activity in sandy loam soil exposed to zinc pressure. Journal of Elementology, 16(4), 577-589.

Lehmann, J., \& Rondon, M. (2006). Bio-char soil management on highly weathered soils in the humid tropics. In N. Uphoff (Ed.), Biological approaches to sustainable soil systems (pp. 517-531). Boca Raton: CRC Press.

Lehmann, J., Rillig, M. C., Thies, J., Masiello, C. A., Hockaday, W. C., \& Crowley, D. (2011). Biochar effects on soil biota-a review. Soil Biology and Biochemistry, 43(9), 1812-1836.
Liang, B., Lehmann, J., Solomon, D., Kinyangi, J., Grossman, J., O’Neill, B., Skjemstad, J. O., Thies, J., Luizão, F. J., Petersen, J., \& Neves, E. G. (2006). Black carbon increases cation exchange capacity in soils. Soil Science Society of America Journal, 70, 1719-1730.

Macdonald, C. A., Campbell, C. D., Bacon, J. R., \& Singh, B. K. (2008). Multiple profling of soil microbial communities identifies potential genetic markers of metal-enriched sewage sludge. FEMS Microbiology Ecology, 65, 555-564.

Mahar, A., Wang, P., Ali, A., Awasthi, M. K., Lahori, A. H., Wang, Q., Li, R., \& Zhang, Z. (2016). Challenges and opportunities in the phytoremediation of heavy metals contaminated soils: a review. Ecotoxicology and Environmental Safety, 126, 111121.

Malandrino, M., Abollino, O., Buoso, S., Giacomino, A., La Gioia, C., \& Mentasti, E. (2011). Accumulation of heavy metals from contaminated soil to plants and evaluation of soil remediation by vermiculite. Chemosphere, 82(2), 169-178.

Moreno, L., Bastida, F., Ros, M., Hernández, T., \& García, C. (2009). Soil organic carbon buffers heavy metal contamination on semiarid soils: effect of different metal thresholds levels on soil microbial activity. European Journal of Soil Biology, 45(3), 220-228.

Orwin, K. H., \& Wardle, D. A. (2004). New indices for quantifying the resistance and resilience of soil biota to exogenous disturbances. Soil Biology and Biochemistry, 36, 1907-1912.

Pérez de Mora, A., Ortega-Calvo, J. J., Cabrera, F., \& Madejón, E. (2005). Changes in enzyme activities and microbial biomass after "in situ" remediation of a heavy metal-contaminated soil. Applied Soil Ecology, 28(2), 125-137.

Sheng, P. X., Ting, Y.-P., Chen, J. P., \& Hong, L. (2004). Sorption of lead, copper, cadmium, zinc, and nickel by marine algal biomass: characterization of biosorptive capacity and investigation of mechanisms. Journal of Colloid and Interface Science, 275(1), 131-141.

StatSoft Inc. 2014. Statistica (data analysis software system), version 12.0. Available at www.statsoft.com.

Steiner, C., Das, K. C., Garcia, M., Förster, B., \& Zech, W. (2008). Charcoal and smoke extract stimulate the soil microbial community in a highly weathered xanthic Ferralsol. Pedobiologia, 51(5), 359-366.

Strachel, R., Wyszkowska, J., \& Bacmaga, M. (2017). The role of compost in stabilizing the microbiological and biochemical properties of zinc-stressed soil. Water, Air, \& Soil Pollution, $228,349$.

Sun, Y., Sun, G., Xu, Y., Wang, L., Liang, X., \& Lin, D. (2013). Assessment of sepiolite for immobilization of cadmiumcontaminated soils. Geoderma, 193-194, 149-155.

Sun, Y., Zhao, D., Xu, Y., Wang, L., Liang, X., \& Shen, Y. (2016). Effects of sepiolite on stabilization remediation of heavy metal-contaminated soil and its ecological evaluation. Frontiers of Environmental Science \& Engineering, 10(1), 85-92.

Szabó, L. P. (2004). Characterization of alginite humic acid content. Desalination, 163, 85-91.

Tica, D., Udovic, M., \& Lestan, D. (2011). Immobilization of potentially toxic metals using different soil amendments. Chemosphere, 85(4), 577-583.

Wieczorek, K., Wyszkowska, J., \& Kucharski, J. (2014). Influence of zinc, copper, nickel, cadmium and lead in soils on acid 
phosphatase activity. Fresenius Environmental Bulletin, 23(1a), 274-284.

Wu, X., Liu, C., Qi, H., Zhang, X., Dai, J., Zhang, Q., Zhang, L., Wu, Y., \& Peng, X. (2016). Synthesis and adsorption properties of halloysite/carbon nanocomposites and halloysitederived carbon nanotubes. Applied Clay Science, 119, 284 293.

Wyszkowska, J., Borowik, A., Kucharski, M., \& Kucharski, J. (2013). Effect of cadmium, copper and zinc on plants, soil microorganisms and soil enzymes. Journal of Elementology, 18(4), 769-796.

Wyszkowska, J., Boros-Lajszner, E., \& Kucharski, J. (2015). Microbiological and biochemical properties of soil contaminated with zinc and fertilized with fermented bark, keratin and cellulose. Fresenius Environmental Bulletin, 24(12a), 4519-4526.

Wyszkowska, J., Boros-Lajszner, E., Borowik, A., Baćmaga, M., Kucharski, J., \& Tomkiel, M. (2016). Implication of zinc excess on soil health. Journal of Environmental Science and Health - Part B, 51(5), 261-270.

Yang, Z. X., Liu, S. Q., Zheng, D. W., \& Feng, S. D. (2006). Effects of cadium, zinc and lead on soil enzyme activities. Journal of Environmental Sciences, 18(6), 1135-1141.

Yuan, P., Tan, D., \& Annabi-Bergaya, F. (2015). Properties and applications of halloysite nanotubes: recent research advances and future prospects. Applied Clay Science, 112, 75-93.

Zacchini, M., Pietrini, F., Mugnozza, G. S., Iori, V., Pietrosanti, L., \& Massacci, A. (2009). Metal tolerance, accumulation and translocation in poplar and willow clones treated with cadmium in hydroponics. Water, Air, \& Soil Pollution, 197, 23-34.

Zhai, R., Zhang, B., Liu, L., Xie, Y., Zhang, H., \& Liu, J. (2010). Immobilization of enzyme biocatalyst on natural halloysite nanotubes. Catalysis Communications, 12(4), 259-263. 